\title{
Origin, Distribution and Evolution of Plume Magmatism in East Antarctica
}

\author{
Nadezhda M. Sushchevskaya ${ }^{1}$, Boris V. Belyatsky² and Anatoly A. Laiba ${ }^{3}$ \\ ${ }^{1}$ Vernadsky Institute of Geochemistry and Analytical Chemistry, \\ Russian Academy of Sciences, Moscow, \\ ${ }^{2}$ All-Russian Research Institute of Geology and \\ Mineral Resources of the World Ocean, St.Petersburg, \\ ${ }^{3}$ Polar Marine Geological Prospecting Survey, St.Petersburg, \\ Russia
}

\section{Introduction}

According to current models (Dalziel et al., 2000; Lawver et al., 1985; Morgan, 1981), the formation of oceanic crust in the South Atlantic and Indian Ocean was affected by large mantle plumes, such as the Karoo-Maud, Kerguelen, and Parana-Etendeka plumes. The penetration of the Karoo-Maud plume into the upper lithosphere at about $180 \mathrm{Ma}$ affected the southern end of Africa and western part of the East Antarctica and was among the main factors that caused the subsequent breakup of the Gondwana supercontinent (Duncan et al., 1997; Jokat et al., 2003; Storey, 1995; Storey \& Kyle, 1997). Later, at about $130 \mathrm{Ma}$, the Kerguelen plume formed near the spreading zone of the opening Indian Ocean (Coffin et al., 2002; Mahoney et al., 1995; Storey et al., 1989, 1992; Weis et al., 1996) which had a considerable impact on the character of oceanic magmatism and resulted in the formation of numerous volcanic rises (Ninetyeast Ridge, Afanasy Nikitin Rise, Naturaliste Plateau, and, probably, Conrad Rise) (Borisova et al., 1996; Frey et al., 2002; Sushchevskaya et al., 1998). Moreover, it affected the continental margins of India (Rajmahal traps) and Australia (Bunbury basalts) (Curray \& Munasinghe, 1991; Frey et al., 1996; Kent et al., 1997, 2002). The plume magmatism of South America and Central Africa was assigned to the activity of another mantle plume, Parana-Etendeka, which caused the formation of a seamount chain, the Walvis Ridge, within the South Atlantic at 130-90 Ma (Renne et al., 1996; Stewart et al., 1996). It is obvious that the interaction of plume and oceanic magmatism has a grate sense for resolving many important problems of marine geology and, primarily, the evolution of the oceanic lithosphere. In addition, plume magmatism provides evidence for deciphering the spatio-temporal spreading of plume materials in the lithosphere (in general sense), determining the timing of plume activity and its evolution under lithospheric conditions, and estimating the influence of plumes on the processes of lithospheric plate disintegrations. In this context, an interesting occurrence of plume activity is the Jurassic magmatism of Antarctica, which has been extensively studied in the past few years (Brewer et al., 1996; Elliot et al., 1999; Elliot \& Fleming, 2000; Harris et al., 1990; Hergt et al., 1991; etc.). It is supposed that the Mesozoic plume magmatism of Antarctica propagated along the weakened zones of the Earth's crust at the margins of the East Antarctica, along the 
Transantarctic Mountains and Indian Ocean coast (Elliot et al., 1999; Leat et al., 2007; White \& McKenzie, 1989). The westernmost occurrences of this magmatism are basalts and dolerites from the western part of the Dronning Maud Land (DML), which have tholeiitic compositions and are geochemically enriched to a varying degree (Harris et al., 1990; Luttinen \& Furnes, 2000; Vuori \& Luttinen 2003). The magmatic complexes of DML (Vestfjella, Heimefrontfjella, and Kirwanveggen mountains and the Ahlmannryggen Plateau) were formed within a narrow time interval between 183 and $175 \mathrm{Ma}$, with the maximum magmatic activity at ca. 178 Ma (Belyatsky et al., 2002; Brewer et al., 2003; Riley et al., 2005; Zhang et al., 2003).

In this paper, we consider the results of a comprehensive geochemical study of the Mesozoic dolerites of the Schirmacher Oasis (Fig. 1), which is situated to the east of the previously studied occurrences of flood-basalt magmatism in western DML. The age and compositions of the Schirmacher dolerites indicate their connection to mantle plume activity (Belyatsky et al., 2006), which provides an opportunity to refine the boundaries of the Karoo-Maud plume spreading beneath Antarctica. In contrast to the Karoo-Maud plume, the Kerguelen plume invaded the already open ocean basin, which had to influence its geochemical signature (Doucet et al., 2005; Storey et al., 1989; Weis et al., 1991; Weis \& Frey, 1996). In addition, we attempted to compare in this paper the geochemical character of DML plume magmatism and magmatism of the early stages of Kerguelen plume activity and present some geodynamic implications on the basis of this comparison.

\section{Geologic setting and composition of the Mesozoic dike complex of the Schirmacher Oasis}

The mountainous Schirmacher Oasis is situated in the central part of DML and composes, together with the adjoining nunataks, the northernmost exposed segment of a large mountain chain extending through the whole region (Fig. 1). The oasis is a belt of hilly outcrops, which extends for $20 \mathrm{~km}$ in an E-W direction at a maximum width of $4 \mathrm{~km}$. The outcrops of the oasis are completely composed of Precambrian metamorphic rocks, which underwent at least two stages of metamorphic transformations, at about 1000 and 500-450 Ma. The oldest rocks of Late Proterozoic age are alaskite metagranites, metadiorites, metadolerites, metamorphosed gabbronorites, and biotite granites. The Early Paleozoic epoch of granite formation produced three compositional series of pegmatites, diorite dikes, and pegmatoid granites. There is a separate group of Silurian dikes and small bodies of alkaline lamprophyres (Hoch \& Tobschall, 1998; Hoch et al., 2001). The complex of Mesozoic dolerites (basic rocks) occurs over the entire Schirmacher Oasis (Fig. 1). The dolerite dikes cut all of the known metamorphic sequences, metagranites and metabasic rocks, veins of pegmatite series, and alkaline lamprophyres occurring within the oasis, which indicates that the dolerites are the youngest igneous rocks of the region. The dikes strike mainly NW-SE and NE-SW and dip 25-90. The thickness of the dikes is $0.1-1.7 \mathrm{~m}$, occasionally up to $8 \mathrm{~m}$. Their lengths are up to $250-270 \mathrm{~m}$ and usually a few tens of meters. With respect to petrographic composition, the dikes are made up of olivine and olivine- free dolerites and gabbro-dolerites affected to a varying degree by secondary alteration.

The dolerites are porphyritic or equigranular rocks with microdoleritic, microgabbroic, or vitrophyric groundmass textures. Sometimes olivine and clinopyroxene phenocrysts account for $10-25 \%$ of the rock by volume (e.g. olivine-phyric dolerite). Chilled margins were observed in the thickest dikes. With respect to chemical composition, the majority of 
basalts and dolerites of the Schirmacher Oasis can be classified as weakly alkaline, but three of them even nepheline normative alkaline, magnesian basalts with 0.6-1.6 wt $\% \mathrm{~K}_{2} \mathrm{O}, 0.7-2.0$ $w t \% \mathrm{TiO}_{2}$, and 10-17 wt $\% \mathrm{MgO}$. Figure 2 shows variations in $\mathrm{TiO}_{2}, \mathrm{~K}_{2} \mathrm{O}, \mathrm{Na}_{2} \mathrm{O}$, and $\mathrm{SiO}_{2}$ as functions of $\mathrm{MgO}$ content for the dolerite samples those compositions are given in Table 1 (oxide compositions were determined by XRF at Vernadsky Institute, detection limits ranged from 0.001 to $0.02 \mathrm{wt} \%$, RSD from 1.5 to $13 \mathrm{wt} \%$; for detailed description of analytical procedure see (Sushchevskaya et al., 2009)). Three samples from our data set (47240-2, 47235-19, and 47201-4) show elevated potassium contents, and sample 47240-2 is also depleted in silica and enriched in alkalis and titanium, which allows classify them as alkali high potassic basalts. Sample 47201-4 is a strongly altered amygdaloidal dolerite, and the presence of amphibole and biotite in sample 47235-19 indicates plausible lamprophiric input, but in any case theirs compositions can be regarded as primary with some caution. Thus, two of the freshest olivine dolerite samples, 47225-7 and 47139-7, were selected for the investigation of major minerals. The Mesozoic metabasites of the Schirmacher Oasis (Fig. 2) are identical in composition to the dolerites of the dike complex of the Muren massif in western DML (Vuori \& Luttinen, 2003) and slightly different from the ancient anorthosite dikes occurring at the Schirmacher Oasis and often showing similar strikes (Belyatsky et al., 2002). In general, the crystallization sequence of the basalts is magnesian olivineplagioclase-clinopyroxene. This is supported by the analyses of minerals, in particular, more magnesian compositions of olivines compared with clinopyroxenes. The olivine composition varies strongly from Fo91.5 to Fo55 ( 400 grains), which suggests the occurrence of crystal accumulation processes during melt differentiation. The most widespread olivine compositions, within Fo88-89, are similar to the most magnesian olivines from the least

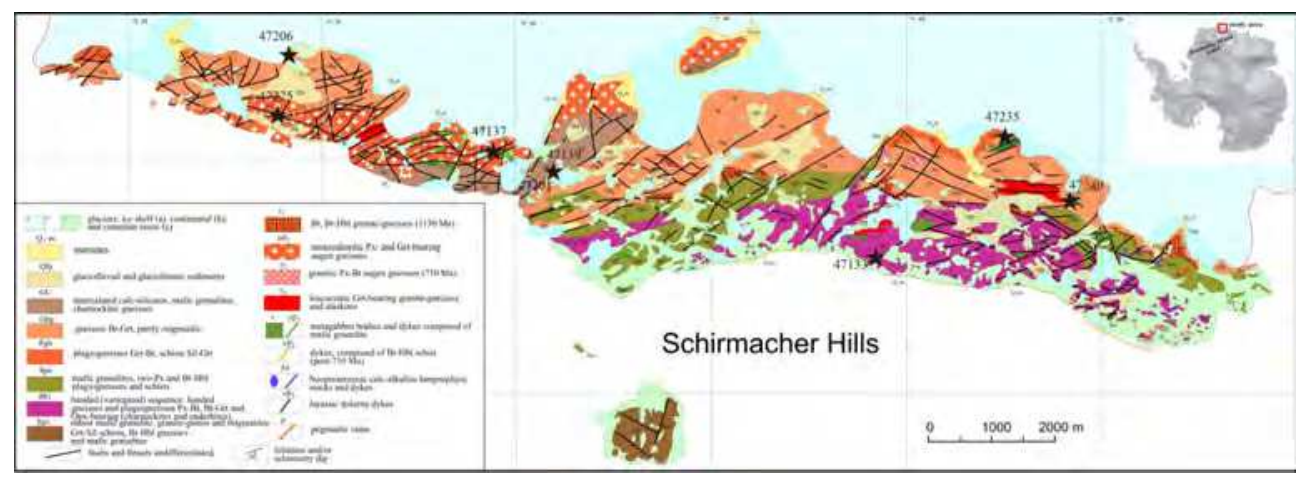

Fig. 1. Simplified geological map of the Schirmacher Oasis region showing sampling sites (asterisks). The distribution of the ice cover is shown by light blue colors, and outcrops of old continental rocks (granulites, gneisses, plagiogranites, schists, etc.) are colored in accordance with insert legend. Tectonic dislocations, ancient dikes of lamprophyres, dolerites, and metagabbroids as well as Jurassic olivine-bearing dolerites and pegmatite veins are shown as lines of corresponded colors. Sample numbers are shown on the map. 


\begin{tabular}{|c|c|c|c|c|c|c|c|c|c|}
\hline component & 47133-1 & $47137-20$ & 47139-7 & $47201-4$ & $47206-3$ & $47225-6$ & $47225-7$ & 47235-19 & $47240-2$ \\
\hline $\mathrm{SiO} 2$ & 49.70 & 45.05 & 44.80 & 51.39 & 45.75 & 42.05 & 44.70 & 51.76 & 36.13 \\
\hline $\mathrm{TiO} 2$ & 1.00 & 1.29 & 0.82 & 1.09 & 1.30 & 2.22 & 1.56 & 1.00 & 3.25 \\
\hline $\mathrm{A} 12 \mathrm{O} 3$ & 15.84 & 12.13 & 9.96 & 10.57 & 12.07 & 11.45 & 12.25 & 14.87 & 11.25 \\
\hline $\mathrm{Fe} 2 \mathrm{O} 3$ & 10.18 & 12.51 & 11.56 & 9.31 & 12.87 & 16.13 & 14.15 & 8.39 & 14.09 \\
\hline $\mathrm{MnO}$ & 0.16 & 0.19 & 0.36 & 0.15 & 0.19 & 0.21 & 0.24 & 0.13 & 0.23 \\
\hline $\mathrm{MgO}$ & 9.91 & 11.34 & 16.49 & 11.25 & 11.89 & 10.95 & 13.05 & 8.01 & 7.56 \\
\hline $\mathrm{CaO}$ & 8.96 & 10.35 & 9.68 & 7.21 & 10.88 & 10.89 & 10.06 & 7.50 & 10.21 \\
\hline $\mathrm{Na2O}$ & 2.56 & 3.18 & 2.14 & 1.04 & 2.21 & 2.94 & 2.68 & 2.72 & 5.39 \\
\hline $\mathrm{K} 2 \mathrm{O}$ & 0.77 & 0.88 & 0.55 & 5.33 & 0.32 & 1.03 & 0.76 & 3.32 & 3.46 \\
\hline P2O5 & 0.18 & 0.30 & 0.20 & 0.91 & 0.18 & 0.31 & 0.25 & 0.51 & 0.64 \\
\hline LOI & 0.88 & 2.62 & 2.62 & 1.16 & 2.07 & 1.57 & 0.28 & 1.30 & 7.35 \\
\hline Total & 100.14 & 99.84 & 99.18 & 99.41 & 99.73 & 99.75 & 99.98 & 99.51 & 99.56 \\
\hline $\mathbf{B a}$ & 304 & 342 & 283 & 4216 & 129 & 313 & 258 & 2765 & 1266 \\
\hline Th & 2.08 & 1.35 & 0.69 & 15.02 & 1.02 & 1.34 & 1.17 & 21.08 & 1.49 \\
\hline $\mathbf{U}$ & 0.43 & 0.34 & 0.16 & 1.58 & 0.16 & 0.24 & 0.21 & 2.47 & 0.44 \\
\hline $\mathrm{Nb}$ & 3.25 & 9.79 & 3.66 & 15.54 & 3.35 & 10.89 & 8.38 & 11.07 & 60.91 \\
\hline $\mathrm{Ta}$ & 0.20 & 0.61 & 0.21 & 0.75 & 0.20 & 0.84 & 0.66 & 0.70 & 7.24 \\
\hline La & 12.70 & 10.24 & 5.34 & 63.72 & 7.06 & 11.92 & 10.15 & 76.17 & 15.58 \\
\hline $\mathrm{Ce}$ & 30.0 & 21.6 & 11.7 & 123.8 & 16.4 & 28.1 & 23.1 & 142.9 & 30.2 \\
\hline $\mathrm{Pb}$ & 5.00 & 2.67 & 2.17 & 9.43 & 1.50 & 4.05 & 2.93 & 49.0 & 5.54 \\
\hline Pr & 4.21 & 2.95 & 1.65 & 14.38 & 2.42 & 4.14 & 3.30 & 16.20 & 3.82 \\
\hline $\mathrm{Sr}$ & 154 & 298 & 286 & 831 & 221 & 352 & 321 & 1064 & 683 \\
\hline $\mathrm{Nd}$ & 19.7 & 14.1 & 8.22 & 58.1 & 12.4 & 20.6 & 16.1 & 63.6 & 17.1 \\
\hline $\mathrm{Sm}$ & 5.27 & 3.70 & 2.34 & 10.38 & 3.61 & 5.59 & 4.36 & 11.06 & 4.04 \\
\hline $\mathrm{Zr}$ & 20 & 83 & 52 & 249 & 83 & 149 & 101 & 177 & 187 \\
\hline Hf & 0.95 & 2.16 & 1.36 & 6.35 & 2.25 & 3.86 & 2.70 & 4.94 & 4.97 \\
\hline $\mathrm{Eu}$ & 1.18 & 1.23 & 0.76 & 2.30 & 1.19 & 1.75 & 1.44 & 2.65 & 1.38 \\
\hline Gd & 5.94 & 3.91 & 2.55 & 7.31 & 3.98 & 5.66 & 4.63 & 8.16 & 4.35 \\
\hline Dy & 6.51 & 3.49 & 2.49 & 5.16 & 3.68 & 4.78 & 4.01 & 5.53 & 3.99 \\
\hline $\mathbf{Y}$ & 36.5 & 17.8 & 12.8 & 26.5 & 18.1 & 22.6 & 18.8 & 26.4 & 18.9 \\
\hline Er & 3.98 & 1.83 & 1.30 & 2.53 & 1.83 & 2.28 & 1.98 & 2.65 & 1.94 \\
\hline $\mathrm{Yb}$ & 3.76 & 1.60 & 1.15 & 2.26 & 1.56 & 1.84 & 1.69 & 2.34 & 1.65 \\
\hline Ho & 1.39 & 0.68 & 0.49 & 0.97 & 0.70 & 0.88 & 0.77 & 1.00 & 0.75 \\
\hline Lu & 0.55 & 0.23 & 0.17 & 0.33 & 0.22 & 0.27 & 0.24 & 0.33 & 0.23 \\
\hline $\mathrm{La} / \mathrm{Nb}$ & 3.91 & 1.05 & 1.46 & 4.10 & 2.11 & 1.09 & 1.21 & 6.88 & 0.26 \\
\hline $\mathrm{La} / \mathrm{Sm}$ & 2.41 & 2.77 & 2.28 & 6.14 & 1.96 & 2.13 & 2.33 & 6.89 & 3.85 \\
\hline $\mathrm{La} / \mathrm{Yb}$ & 3.38 & 6.40 & 4.67 & 28.24 & 4.54 & 6.49 & 6.00 & 32.49 & 9.46 \\
\hline $\mathrm{Sr} / \mathrm{Nd}$ & 7.79 & 21.07 & 34.73 & 14.29 & 17.82 & 17.10 & 19.91 & 16.74 & 40.02 \\
\hline $\mathrm{Gd} / \mathrm{Yb}$ & 1.58 & 2.44 & 2.23 & 3.24 & 2.56 & 3.08 & 2.74 & 3.48 & 2.64 \\
\hline $\mathrm{La} / \mathrm{Ce}$ & 0.42 & 0.47 & 0.46 & 0.51 & 0.43 & 0.42 & 0.44 & 0.53 & 0.52 \\
\hline${ }^{147} \mathrm{Sm} /{ }^{144} \mathrm{Nd}$ & 0.16061 & 0.15862 & 0.16814 & 0.10985 & 0.17377 & 0.16212 & 0.16068 & 0.10522 & 0.14251 \\
\hline${ }^{143} \mathrm{Nd} /{ }^{244} \mathrm{Nd}$ & 0.512536 & 0.512569 & 0.512649 & 0.511578 & 0.512720 & 0.512656 & 0.512585 & 0.511953 & 0.512695 \\
\hline err (2S) & 0.000004 & 0.000004 & 0.000004 & 0.000004 & 0.000002 & 0.000003 & 0.000008 & 0.000006 & 0.000005 \\
\hline${ }^{87} \mathrm{Rb} /{ }^{6} \mathrm{Sr}$ & 0.59815 & 0.46261 & 1.13929 & 0.88193 & 0.14066 & 0.24536 & 0.23932 & 0.29299 & 0.77902 \\
\hline${ }^{87} \mathrm{Sr} /{ }^{4} \mathrm{Sr}$ & 0.711137 & 0.706852 & 0.707522 & 0.714170 & 0.704928 & 0.705283 & 0.705227 & 0.709301 & 0.705929 \\
\hline err (2S) & 0.000015 & 0.000006 & 0.000019 & 0.000017 & 0.000015 & 0.000021 & 0.000014 & 0.000008 & 0.000005 \\
\hline eNd & -1.21 & -0.52 & 0.83 & -18.80 & 2.10 & 1.10 & -0.25 & -11.38 & 2.29 \\
\hline$\left.{ }^{5 /} \mathrm{Sr} / \mathrm{s} \mathrm{Sr}\right) \mathrm{t}$ & 0.70969 & 0.70573 & 0.70477 & 0.71204 & 0.70459 & 0.70469 & 0.70465 & 0.70859 & 0.70405 \\
\hline${ }^{206} \mathrm{~Pb} /{ }^{204} \mathrm{~Pb}$ & 18.202 & 18.936 & 18.149 & 18.197 & 17.969 & 18.062 & 17.925 & 17.360 & 18.619 \\
\hline${ }^{207} \mathrm{~Pb} /{ }^{204} \mathrm{~Pb}$ & 15.559 & 15.573 & 15.494 & 15.535 & 15.508 & 15.511 & 15.494 & 15.511 & 15.510 \\
\hline${ }^{2035} \mathrm{~Pb} /{ }^{204} \mathrm{~Pb}$ & 38.118 & 38.274 & 37.934 & 39.621 & 38.176 & 38.208 & 38.137 & 37.810 & 38.192 \\
\hline
\end{tabular}

Table 1. Major (vol\%) and trace element (ppm) concentrations, and $\mathrm{Sr}, \mathrm{Nd}$, and $\mathrm{Pb}$ isotope data for rocks of basalts and dolerites from Schirmacher Oasis. LILE concentration and isotope analysis were determined at Karpinsky Geological Institute (St.Petersburg, Russia) by ICP MS (detailed in Sushchevskaya, et al. 2009). err (2S) - corresponds to isotope ratios error at $95 \%$ confidence level. eNd and $\left({ }^{87} \mathrm{Sr} / 86 \mathrm{Sr}\right) \mathrm{t}$ - initial isotope composition corresponding sample at the time of dike emplacement (170 Ma). 

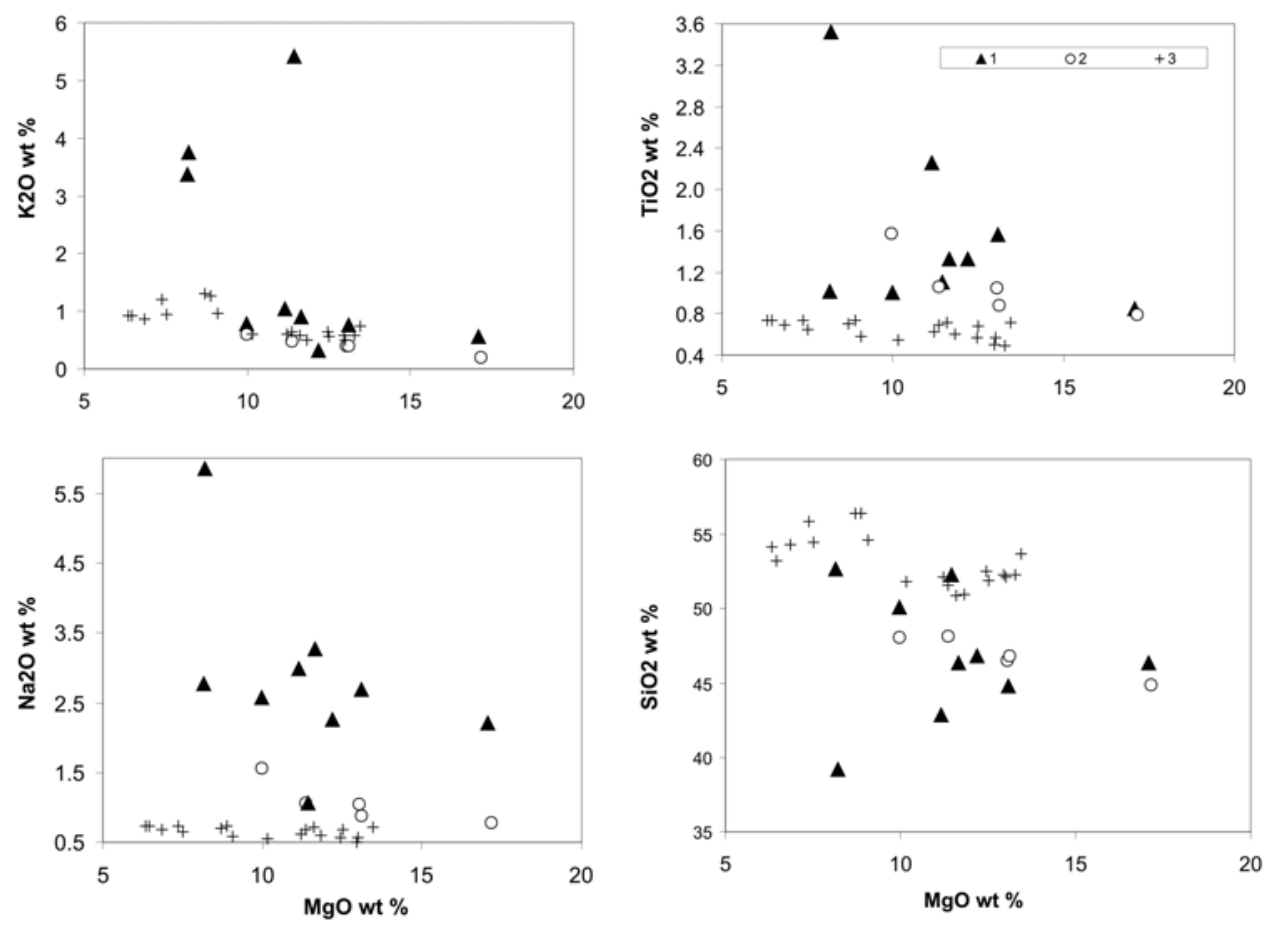

Fig. 2. Variations in major element contents for the Schirmacher dolerites. (1) Dolerites of the Schirmacher Oasis (Table 1), (2) dikes of the Muren region of DML after (Vuori \& Luttinen, 2003), and (3) ancient anorthosite dikes from the Schirmacher Oasis region (Belyatsky et al., 2002).

differentiated Jurassic lavas of the western DML (Sushchevskaya et al., 2004). The distinctive feature of the Schirmacher dolerites is the presence of Mg-rich olivines (Fo90-91), which may indicate rapid magma ascent from the generation zones (Fig. 3). Variations in $\mathrm{Ca}$ and $\mathrm{Ni}$ as a function of forsterite content reflect a decrease in $\mathrm{Ni}$ and an increase in Ca contents during primary magma crystallization. In addition, it can be clearly seen in the diagrams that the points of olivine compositions from the two studied samples form two independent trends of $\mathrm{NiO}$ and $\mathrm{MnO}$ variations with different slopes. The average $\mathrm{NiO}$ content in the most magnesian olivines is $\sim 0.35 \mathrm{wt} \%(\mathrm{~N}=340)$ for sample $47139-7, \sim 0.4 \mathrm{wt} \%(\mathrm{~N}=46)$ for sample $47225-7$, and $\sim 0.5 \mathrm{wt} \%$ for olivines from the Vestfjella Mountains (western DML) (Fig. 3). The differences in $\mathrm{Ni}$ content of the liquidus olivines are primarily related to different $\mathrm{Ni}$ contents in the initial melts. According to the suggested model of Sobolev with colleagues (Sobolev et al., 2007), an increase in $\mathrm{NiO}$ and a decrease in $\mathrm{MnO}$ content in magnesian olivines indicate the presence of pyroxenite blobs and veins in the peridotite source. The highest contribution of such a crustal component was inferred for olivines from DML rocks (Sushchevskaya et al., 2004). The model was initially proposed for Hawaiian magmas (Sobolev et al., 2005) and assumed that their plume source contained fragments of crustal eclogites (i.e. lower crustal substance), whose melting began during the ascent of the heterogeneous mantle material at a depth of about $150 \mathrm{~km}$. The produced melts reacted with the peridotite matrix, which resulted 
in the formation of pyroxenites with Ni-rich pyroxenes. The further melting of pyroxenites at a depth of about $100 \mathrm{~km}$ resulted in the formation of melts enriched in Ni relatively the liquids that could be produced by the melting of a peridotite source. The question on the reasons of the heterogeneity of the plume mantle remains unresolved. It could be related to processes accompanying material ascent from the core-mantle boundary, where subducted fragments of the early oceanic crust probably are accumulated (Chase \& Patchett, 1988; Christensen \& Hofmann, 1994; Hofmann, 1988; Ono et al., 2001; etc.), or to the interaction of the ascending hot peridotitic mantle with the lower parts of continental blocks at depths of 170-220 km (O'Reilly \& Griffin, 2010). In either case, eclogite melting could result in the appearance of pyroxenites and their subsequent involvement into the derivation of basaltic magmas (Sobolev et al., 2007). It should be pointed out that, during the initial activity of the plume that was located in the DML region of Antarctica (Leitchenkov \& Masolov, 1997; Leitchenkov et al., 2003), this process was more intense, which is reflected in the higher $\mathrm{NiO}$ contents of magnesian olivines (Fig. 3).
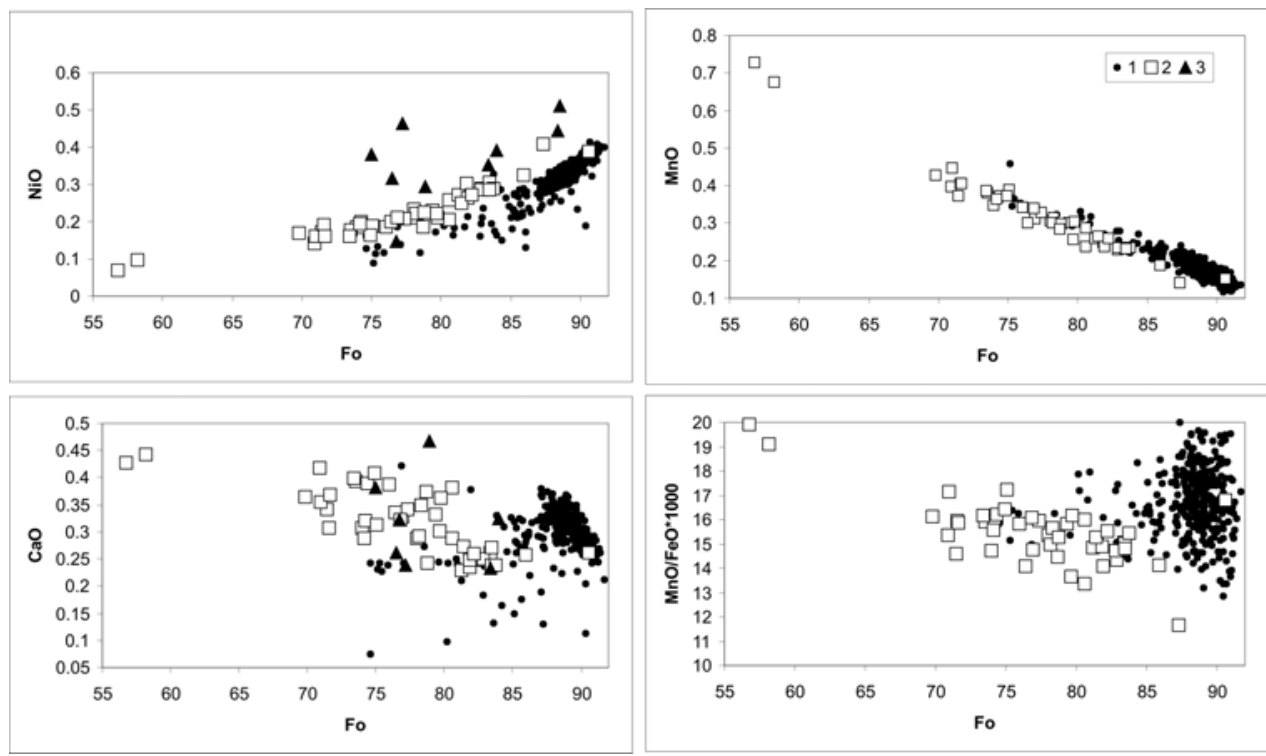

Fig. 3. Contents of $\mathrm{NiO}, \mathrm{CaO}$, and $\mathrm{MnO}$ in olivines from the Schirmacher Oasis dikes as a function of forsterite mole percentage. Olivines from (1) sample 47139-7, (2) sample 47225-7, and (3) DML basalts (Sushchevskaya et al., 2004).

Clinopyroxene is the third phase crystallizing after olivine and plagioclase. It shows variable $\mathrm{Mg}$ value, from 69 to 81 (Fig. 4), and low $\mathrm{Cr} / \mathrm{Al}$ (0.01-0.14) and $\mathrm{Na} / \mathrm{Al}$ ratios (0.10-0.15). In all compositional parameters, including the content of lithophile elements (Migdisova et al., 2004), it is similar to clinopyroxenes from the basalts of the Vestfjella Mountains (western DML). The majority of magnesian olivines contain chrome spinel inclusions (Fig. 5a), whose compositions were used to estimate the redox conditions of crystallization. The obtained values suggest that the early crystallization of magmas occurred near the quartz-fayalitemagnetite buffer $(\mathrm{QFM}), \triangle \mathrm{QFM}$ (deviation of $-\lg \left(f_{\mathrm{O} 2}\right)$ from the QFM value) is $1.0-1.2$. The conditions of magma fractionation were estimated for the Schirmacher Oasis according the compositions of clinopyroxene by the method of (Nimis \& Ulmer, 1998). Using a database of 
experiments with basanite and picrite - basalt starting materials (more than 100 references and 16 unpublished experiments), empirical pressure dependence was derived for the unitcell volume and the volume of the M1 site of clinopyroxene. At a given pressure, the unitcell volume $\left(\mathrm{V}_{\text {cell }}\right)$ is almost linearly correlated with the volume of the $\mathrm{M} 1$ site $\left(\mathrm{V}_{\mathrm{M} 1}\right)$, and, for a given melt composition, $\mathrm{V}_{\text {cell }}$ and $\mathrm{V}_{\mathrm{M} 1}$ decrease linearly with increasing pressure. Using these correlations, pressure can be expressed as a linear function of $\mathrm{V}_{\text {cell }}$ and $\mathrm{V}_{\mathrm{M} 1}$. For anhydrous and water-saturated magmas, the uncertainty is no higher than $1.70 \mathrm{kbar}$ (the highest discrepancy is $5.4 \mathrm{kbar}, \mathrm{N}=157$ ) (Nimis \& Ulmer, 1998). Our estimations suggest shallow depths of magma crystallization in a transitional magma chamber at pressures of about 1-2 kbar. The histograms of model depths of melt crystallization (Fig. 5b) calculated for the temperature $\mathrm{T}=1100^{\circ} \mathrm{C}$ (average temperature of crystallization in a transitional chamber estimated by the COMAGMAT program (Migdisova et al., 2004)) show that the same range of pressures is also typical for the fractionation of basaltic magmas from the DML region.

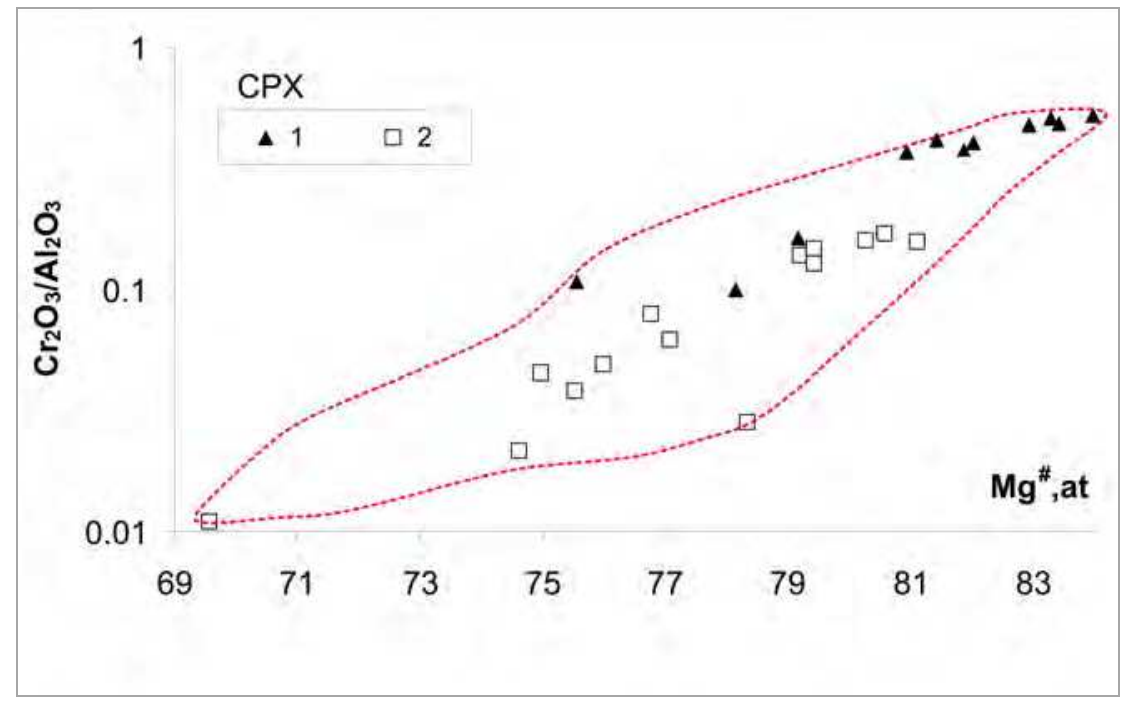

Fig. 4. Composition of clinopyroxene from (1) Schirmacher Oasis dolerites and (2) DML basalts (Sushchevskaya et al., 2004).

Emplacement 130-105 m.y. ago of dikes and sills of alkaline-ultrabasic composition within Jetty oasis (or Jetty Peninsula, Fig. 6a) is suggested as a later appearance of plume magmatism within the East-Antarctic Shield (Andronikov et al., 1993, 2001; Laiba et al., 1987). This region is located opposite Kerguelen Islands and possibly could be properly connected with activity of the Kerguelen-plume (Foley et al., 2001, 2006). JurassicCretaceous dikes, stocks and sills of alkaline-ultrabasic rocks, relatively close to kimberlitetype, are exposed within Jetty oasis and on the southern shore of the Radock Lake (Mikhalsky et al., 1992). This alkaline-ultrabasic magmatism has appeared to be connected with the main Mesozoic stage of the evolution of the Lambert and Amery glaciers riftogenic structure (Kurinin et al., 1980, 1988). The alkaline-ultrabasic dikes and sills within Jetty oasis 


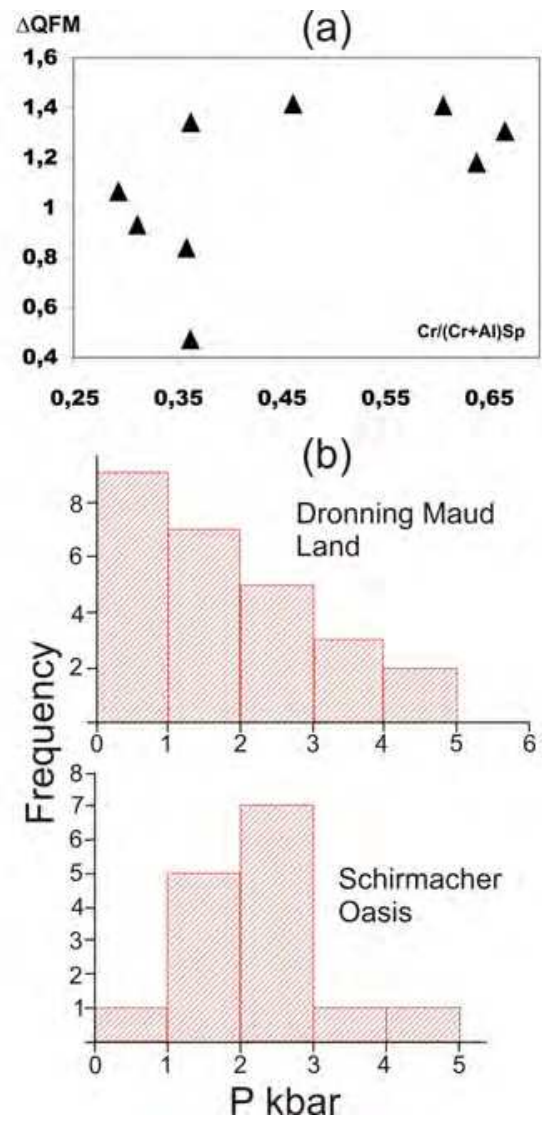

Fig. 5. Estimation of (a) oxygen fugacity, $\mathrm{Cr} /(\mathrm{Cr}+\mathrm{Al})$ ratio of spinel, and (b) pressure of magma crystallization in the intermediate magma chambers of the Schirmacher Oasis and DML. The data for pyroxenes from the DML rocks are after (Sushchevskaya et al., 2004).

cut the rocks of the Beaver complex, Permo-Triassic terrigeneous successions of the Amery complex, and late Paleozoic low-alkaline basic dikes as well. Dashed chain of 6 stock bodies spread out on $15 \mathrm{~km}$ along the eastern shore of the Beaver Lake, marked their allocation with submeridianal zone of the deep cracks, boarded of the eastern side of the Beaver Lake trough. Some of the polzenite and biotite-pyroxene alkaline picrite dikes were discovered on Kamenistaya Platform (northern extremity of Jetty Peninsula, Fig.6a). They have northnorth-eastern strike, subvertical dip and are 0.5-1.0 m thick. Oasis Jetty alkaline bodies on the present-day erosion surface have oval, rare isometric forms from $10 \times 25$ to $80 \times 120 \mathrm{~m}$; dike bodies reach up to $180 \mathrm{~m}$ long and thickness is about $2 \mathrm{~m}$ (Fig. 6b). All of these dike rocks are abundant in mantle nodules, mainly peridotites, and numerous xenoliths of the host Permo-Triassic sediments and Precambrian metamorphics as well (Fig. 6c). It has been suggested that the alkaline-ultrabasic bodies were intruded into two phases. In the elder bodies (130-120 Ma, Yuzhnoe and Severnoe stocks) biotite-pyroxene alkaline picrites prevail, at the same time the younger (120-105 Ma, Novoe and Ploskoe stocks) is composed by polzenites and/or melanephelinites (Laiba et al., 1987; Mikhalsky et al., 1998) (Fig. 6). 

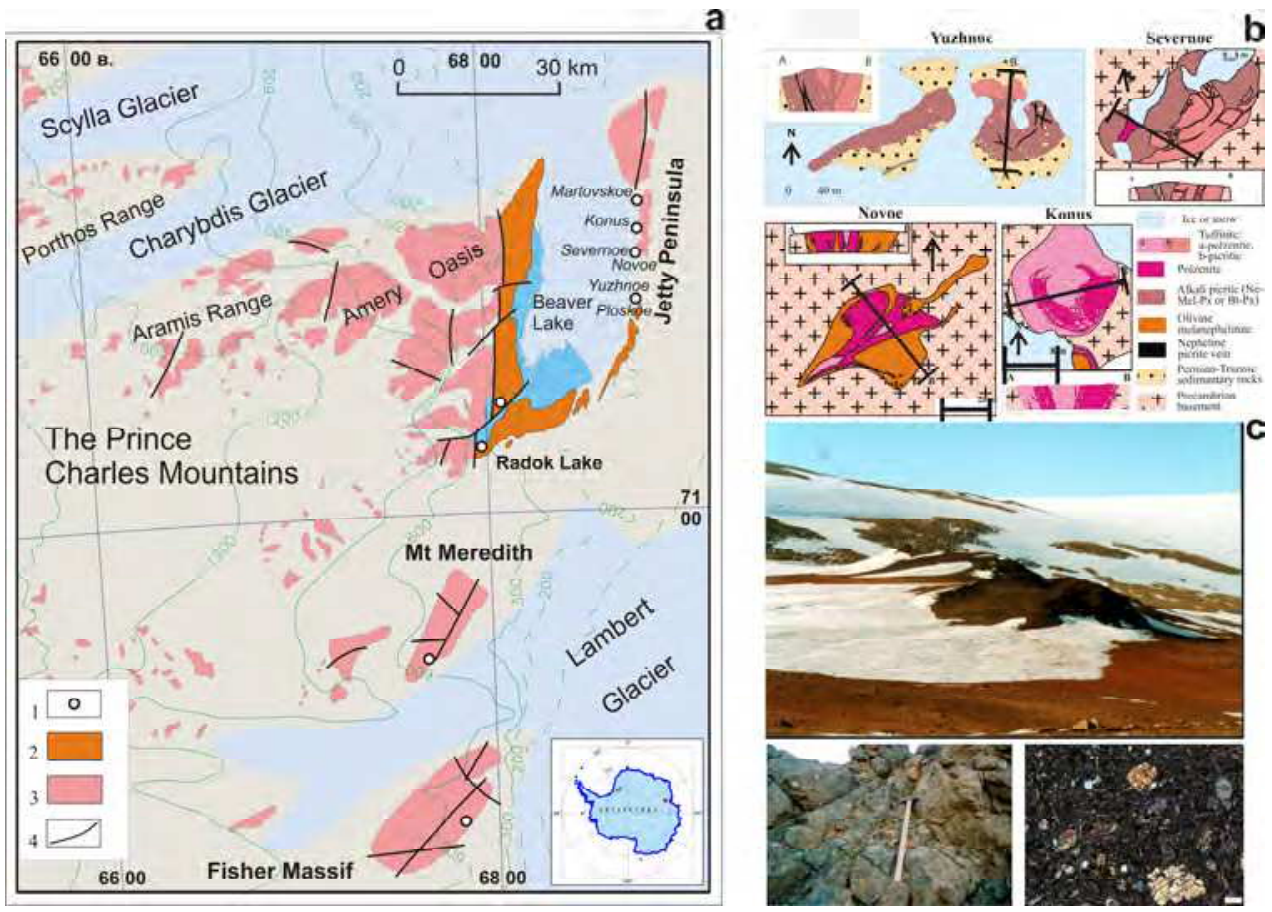

Fig. 6. Geological sketch map showing occurrences of alkaline-ultramafic rocks in the northern and central parts of the Prince Charles Mountains (a): 1- Jurassic-Cretaceous alkaline picrites, 2 - Permian-Triassic coal-dearing deposits, 3 - Precambrian rocks, 4 faults; (b) schematic structure of the alkaline-ultramafic stock-like bodies from Jetty Oasis; (c) general view of the Severnoe stock, detail of outcrop and optic microfoto of tuffisite in crossed nicols.

The investigated samples are characterized by average composition: $\mathrm{SiO}_{2}=37.44, \mathrm{MgO}=$ $19.38, \mathrm{TiO}_{2}=2.26, \mathrm{CaO}=15.42, \mathrm{Fe}_{2} \mathrm{O}_{3}=11.65 \%$, and high enough alkalis: $\mathrm{Na}_{2} \mathrm{O}=2.33$ and $\mathrm{K}_{2} \mathrm{O}=2.49 \%$. The initial $\mathrm{Sr}$ and $\mathrm{Nd}$ isotope compositions of samples are close to the ranges of the values for dolerites from the Schirmacher Oasis. The alkaline picrites show initial

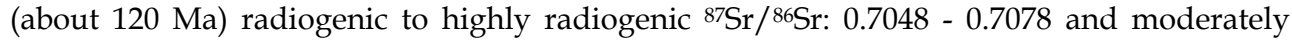
radiogenic to unradiogenic $\varepsilon \mathrm{Nd}$ : from +4 to -7 (Table 2 ).

\section{Geochemical characteristics of the Mesozoic basites of the Schirmacher Oasis}

The contents of lithophile elements in the samples are given in Table 1 and illustrated in the spider diagram (Fig. 7). The primitive mantle-normalized (Sun \& McDonough, 1989) element contents (they are arranged in the diagram in the sequence of decreasing incompatibility) indicate different degrees of lithophile element enrichment in the dolerites. Most of them demonstrate distinct positive $\mathrm{Pb}$, and negative $\mathrm{Ta}$ and $\mathrm{Nb}$ anomalies (Fig. 7a). Similar distribution patterns of lithophile elements were previously observed by us in the tholeiitic basalts of the ancient volcanic rise of Afanasy Nikitin (90-80 Ma), which is situated in the 
central part of the Indian Ocean (Borisova et al., 2001; Sushchevskaya et al., 1996) (Fig. 7d). Noteworthy that alkaline picrites of Jetty Oasis (Fig. $7 \mathrm{~b}$ ) have similar enrichment patterns also. Some of them show pronounced negative $\mathrm{Nb}$ and $\mathrm{Ta}$ anomalies, less apparent positive $\mathrm{Pb}$ anomaly, and negative $\mathrm{Zr}$ and $\mathrm{Hf}$ anomalies. All such samples are from lamprophyre dykes from the outcrop near the Beaver Lake (32R-A101, 32R-A58) and Yuzhnoe body (U-22) (Fig. 6). As these samples do not differ in main composition from the other samples (Table 2) there could be some heterogeneity in the melting source which provides local anomalies for these elements, but in any case the geochemistry points to a high lamprophyric contribution that means very deep melts linked to intraplate plume activity.
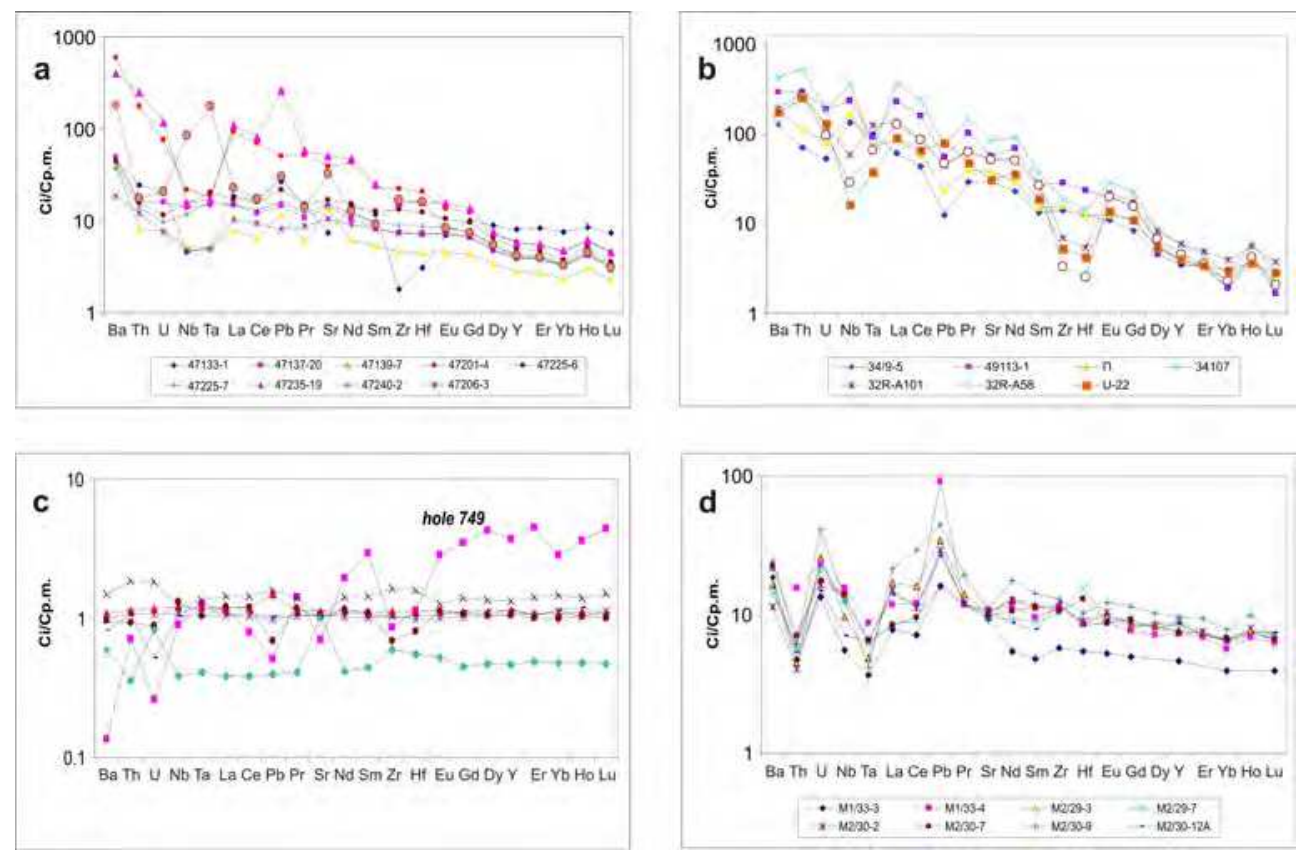

Fig. 7. Primitive mantle-normalized (Sun \& McDonough, 1989) distribution of lithophile element patterns in the Schirmacher Oasis dolerites (a), Jetty Oasis alkaline picrites (b), Kerguelen Plateau tholeiites (Frey et al., 2000) (c) and the Afanasy Nikitin Rise tholeiites (Borisova et al., 2001) (d).

Two samples from our data set show a peculiar lithophile element distribution. In particular, sample 47235-19, which was classified as a derivative of alkaline magmas (lamprophyre-like), shows high contents of all elements, but retains all of the specific geochemical anomalies. With respect to these characteristics, it is most similar to altered dolerite sample 47201-4 that means the both of specimens are from alkaline lamprophyre deep-mantle source. The normalized distribution patterns of lithophile elements in specimen $47420-2$ show a strong positive $\mathrm{Ta}-\mathrm{Nb}$ anomaly but at the same time the mineral composition of the sample is characterized by absent of any signs of titanates (Fig. 7a), which emphasizes the different origin of the geochemical enrichment of its source compared with the majority of studied samples. 


\begin{tabular}{|c|c|c|c|c|c|c|c|}
\hline $\begin{array}{c}\mathrm{NN} \\
\text { locality }\end{array}$ & $\begin{array}{c}34 / 9-5 \\
\text { Yuzhnoe stock }\end{array}$ & $\begin{array}{c}49113-1 \\
\text { Meredit massif }\end{array}$ & $\begin{array}{c}\Pi-4 \\
\text { Ploskoe stock }\end{array}$ & $\begin{array}{c}34107 \\
\text { Fisher Massif }\end{array}$ & $\begin{array}{r}\text { 32R-A101 } \\
\text { Beaver Lake }\end{array}$ & $\begin{array}{c}\text { 32R-A58 } \\
\text { Beaver Lake }\end{array}$ & $\begin{array}{c}\text { U-22 } \\
\text { Yuzhnoe stock }\end{array}$ \\
\hline $\mathrm{SiO} 2$ & 40.6 & 31.4 & 39.3 & 19.3 & 33.65 & 32.79 & 35.76 \\
\hline $\mathrm{TiO} 2$ & 2.24 & 2.34 & 2.25 & 1.50 & 2.00 & 2.20 & 1.5 \\
\hline $\mathrm{Al} 2 \mathrm{O} 3$ & 9.94 & 4.59 & 9.21 & 2.88 & 10.75 & 7.58 & 5.34 \\
\hline $\mathrm{Cr} 2 \mathrm{O} 3$ & 0.042 & 0.069 & 0.048 & 0.059 & 0.06 & 0.08 & 0.1 \\
\hline $\mathrm{Fe} 2 \mathrm{O} 3$ & 11.5 & 10.6 & 10.3 & 14.2 & 1.3 & 4.79 & 2.31 \\
\hline $\mathrm{FeO}$ & & & & & 7.88 & 5.3 & 6.7 \\
\hline $\mathrm{MnO}$ & 0.161 & 0.163 & 0.154 & 0.199 & 0.19 & 0.16 & 0.17 \\
\hline $\mathrm{MgO}$ & 14.1 & 25.0 & 13.6 & 15.1 & 14.66 & 14.35 & 23.73 \\
\hline $\mathrm{CaO}$ & 10.8 & 10.9 & 11.4 & 22.9 & 15.20 & 16.02 & 8.69 \\
\hline $\mathrm{Na} 2 \mathrm{O}$ & 2.21 & $<.05$ & 2.5 & $<.05$ & 2.29 & 1.91 & 1.42 \\
\hline $\mathrm{K} 2 \mathrm{O}$ & 2.09 & 2.63 & 2.3 & 0.612 & 3.53 & 2.52 & 1.8 \\
\hline $\mathrm{P} 2 \mathrm{O} 5$ & 0.51 & 0.818 & 0.657 & 1.95 & 0.83 & 0.73 & 0.63 \\
\hline LOI & 5.65 & 11.2 & 8.14 & 20.8 & 7.41 & 11.83 & 12.18 \\
\hline Total & 99.8 & 99.6 & 99.8 & 99.5 & 99.75 & 100.26 & 100.33 \\
\hline $\mathrm{CO} 2$ & 3.45 & 6.94 & 6.31 & 16.59 & 3.87 & 6.18 & 8.9 \\
\hline $\mathrm{Ba}$ & 903 & 2080 & 1250 & 2950 & 1373.6 & 1061.8 & 1233 \\
\hline Th & 6.13 & 24.9 & 9.94 & 45.5 & 23.83 & 22.22 & 21.8 \\
\hline $\mathrm{U}$ & 1.14 & 3.99 & 1.72 & 3.96 & 2.512 & 2.107 & 2.808 \\
\hline $\mathrm{Nb}$ & 96.4 & 171 & 121 & 260 & 42.23 & 21.02 & 11.87 \\
\hline $\mathrm{Ta}$ & 4.18 & 3.92 & 3.07 & 2.81 & 5.141 & 2.782 & 1.585 \\
\hline La & 42.7 & 159 & 60.9 & 261 & 96.33 & 89.06 & 63.65 \\
\hline $\mathrm{Ce}$ & 79.3 & 285 & 108 & 434 & 161.3 & 154.3 & 120.3 \\
\hline $\mathrm{Pb}$ & 2.39 & 10.4 & 4.47 & 14.3 & 8.438 & 8.884 & 14.96 \\
\hline $\operatorname{Pr}$ & 8.37 & 28.8 & 11 & 40.1 & 18.61 & 17.56 & 13.44 \\
\hline $\mathrm{Sr}$ & 642 & 1220 & 828 & 1830 & 1141.4 & 1119.3 & 667.8 \\
\hline $\mathrm{Nd}$ & 32.3 & 95.9 & 40.6 & 128 & 72.98 & 69.02 & 50 \\
\hline $\mathrm{Sm}$ & 6.17 & 12.3 & 6.95 & 17.1 & 13.11 & 12.19 & 8.715 \\
\hline $\mathrm{Zr}$ & 162 & 328 & 182 & 216 & 81.25 & 38.87 & 61.78 \\
\hline Hf & 3.87 & 7.55 & 4.02 & 4.54 & 1.747 & 0.8077 & 1.351 \\
\hline $\mathrm{Eu}$ & 1.91 & 3.47 & 2.15 & 5.05 & 3.783 & 3.462 & 2.38 \\
\hline $\mathrm{Gd}$ & 5.2 & 10.1 & 6.82 & 13.9 & 10.69 & 9.484 & 6.733 \\
\hline Dy & 3.53 & 4.65 & 4.18 & 6.77 & 6.341 & 5.129 & 4.155 \\
\hline $\mathrm{Y}$ & 16.4 & 17.2 & 18.7 & 27.5 & 28.52 & 21.43 & 19.32 \\
\hline Er & 1.71 & 1.62 & 1.67 & 2.28 & 2.465 & 1.788 & 1.71 \\
\hline $\mathrm{Yb}$ & 0.99 & 0.99 & 1.21 & 1.39 & 2.016 & 1.196 & 1.535 \\
\hline Ho & 0.63 & 0.72 & 0.67 & 1.03 & 0.9395 & 0.7165 & 0.6183 \\
\hline $\mathrm{Lu}$ & 0.16 & 0.13 & 0.18 & 0.22 & 0.2862 & 0.1622 & 0.2205 \\
\hline Sm, ppm & 6.736 & 15.17 & 9.586 & 20.42 & 12.79 & 10.09 & 7.096 \\
\hline $\mathrm{Nd}, \mathrm{ppm}$ & 34.28 & 102.7 & 40.45 & 133.3 & 74.27 & 59.49 & 46.73 \\
\hline${ }^{147} \mathrm{Sm} /{ }^{144} \mathrm{Nd}$ & 0.11876 & 0.08930 & 0.14323 & 0.09257 & 0.10442 & 0.10281 & 0.09209 \\
\hline${ }^{143} \mathrm{Nd} /{ }^{144} \mathrm{Nd}$ & 0.512656 & 0.512426 & 0.512630 & 0.512497 & 0.512783 & 0.512721 & 0.512240 \\
\hline $2 \mathrm{~s}, \mathrm{abs}$ & 0.000003 & 0.000003 & 0.000003 & 0.000006 & 0.000018 & 0.000008 & 0.000016 \\
\hline $\mathrm{Rb}, \mathrm{ppm}$ & 46.53 & 96.96 & 113.3 & 21.81 & 124.5 & 110.8 & 65.87 \\
\hline $\mathrm{Sr}, \mathrm{ppm}$ & 734.8 & 1386.7 & 1204.9 & 2007.9 & 1048.7 & 1778.7 & 674.1 \\
\hline $\begin{array}{c}{ }^{87} \mathrm{Rb} /{ }^{86} \mathrm{Sr} \\
2 \mathrm{~s}, \%\end{array}$ & $\begin{array}{c}0.18319 \\
1.00\end{array}$ & $\begin{array}{c}0.20229 \\
1.27\end{array}$ & $\begin{array}{c}0.27200 \\
7.03\end{array}$ & $\begin{array}{c}0.03142 \\
1.56\end{array}$ & $\begin{array}{c}0.34345 \\
1.00\end{array}$ & $\begin{array}{c}0.18037 \\
1.72\end{array}$ & $\begin{array}{c}0.28268 \\
0.98\end{array}$ \\
\hline${ }^{87} \mathrm{Sr} /{ }^{86} \mathrm{Sr}$ & 0.705167 & 0.706082 & 0.705502 & 0.704926 & 0.705148 & 0.720677 & 0.707207 \\
\hline $2 \mathrm{~s}, \mathrm{abs}$ & 0.000009 & 0.000006 & 0.000005 & 0.000005 & 0.000028 & 0.000014 & 0.000023 \\
\hline $\begin{array}{c}{ }^{206} \mathrm{~Pb}^{/ 204} \mathrm{~Pb} \\
2 \mathrm{~s} \text {, abs }\end{array}$ & $\begin{array}{c}18.702 \\
0.004\end{array}$ & $\begin{array}{c}18.558 \\
0.001\end{array}$ & $\begin{array}{l}18.621 \\
0.0004\end{array}$ & $\begin{array}{c}18.446 \\
0.002\end{array}$ & & & \\
\hline${ }^{207} \mathrm{~Pb}^{/ 204} \mathrm{~Pb}$ & 15.563 & 15.618 & 15.574 & 15.623 & & & \\
\hline $2 \mathrm{~s}, \mathrm{abs}$ & 0.003 & 0.001 & 0.0004 & 0.002 & & & \\
\hline${ }^{208} \mathrm{~Pb}^{/ 204} \mathrm{~Pb}$ & 39.227 & 39.068 & 38.895 & 39.292 & & & \\
\hline $2 \mathrm{~s}$, abs & 0.008 & 0.002 & 0.001 & 0.002 & & & \\
\hline
\end{tabular}

Table 2. Chemical and isotope composition of whole-rock alkaline picrite samples from Jetty Oasis. Major oxides express as wt \% and trace elements - as ppm. All analyses were done at Karpinsky Geological Institute (St.Petersburg, Russia) by ICP MS and solid-source HR MS (isotope analysis) (detailed in (Sushchevskaya et al. 2009). 2s, abs and 2s, \% - correspond to isotope ratio errors (absolute and relative) at 95\% confidence level ( 2 sigmas). 
Tholeiites exposed in drill hole 749 (Southern Kerguelen Plateau) have the age about 114 Ma and belong to the early stages of Kerguelen Plateau formation which maximum age is estimated as $120 \mathrm{Ma}$ (Coffin et al., 2002). Normalized lithophile element patterns of the tholeiites reflect the presence of weakly enriched source and enriched one with pronounced $\mathrm{Zr}$ and Hf negative anomaly for a part of samples as well (Fig. 7c) which mantle enrichment processes supposed to be connected with metasomatic acting of lamprophyric melts (Ingle et al., 2002).

The correlation analysis of lithophile element contents in the basites of the Schirmacher Oasis (as an example, element-Th correlation diagrams are shown in Fig. 8) reveals close relations between $\mathrm{U}$ and $\mathrm{Th}, \mathrm{Pb}$ and $\mathrm{Th}, \mathrm{La}$ and $\mathrm{Th}$, and $\mathrm{Yb}$ and $\mathrm{Th}$ and poor correlations between other lithophile elements. These relations are less obvious for sample 47133-1, which has relatively low contents of $\mathrm{Ta}, \mathrm{Nb}, \mathrm{Hf}, \mathrm{Zr}$, and $\mathrm{Sr}$. For the sake of comparison, Figure 8 shows the fields of enriched tholeiites from the Kerguelen Plateau recovered at ODP site 749 (Frey et al., 2000). It should be noted that the Schirmacher basites are distinguished by lower contents of $\mathrm{Yb}$ and $\mathrm{Hf}$, and, probably, $\mathrm{Sr}$, but the similar ratios of the majority of incompatible elements (especially, $\mathrm{Ta} / \mathrm{Th}, \mathrm{U} / \mathrm{Th}$, and $\mathrm{Pb} / \mathrm{Th}$ ) suggest similar geochemical nature of the enriched sources of both of the magma types. On the other hand, dolerites of the Schirmacher Oasis show higher contents of the majority of lithophile elements compared with tholeiitic basalts of the Kerguelen Plateau. At this time dolerites of the Schirmacher Oasis by many geochemical characteristics are close to alkaline picrites of Jetty Oasis. Origin of the latter is directly connected with the melting of continental lithospheric mantle (Andronikov \& Egorov, 1993; Andronikov \& Foley, 2001).

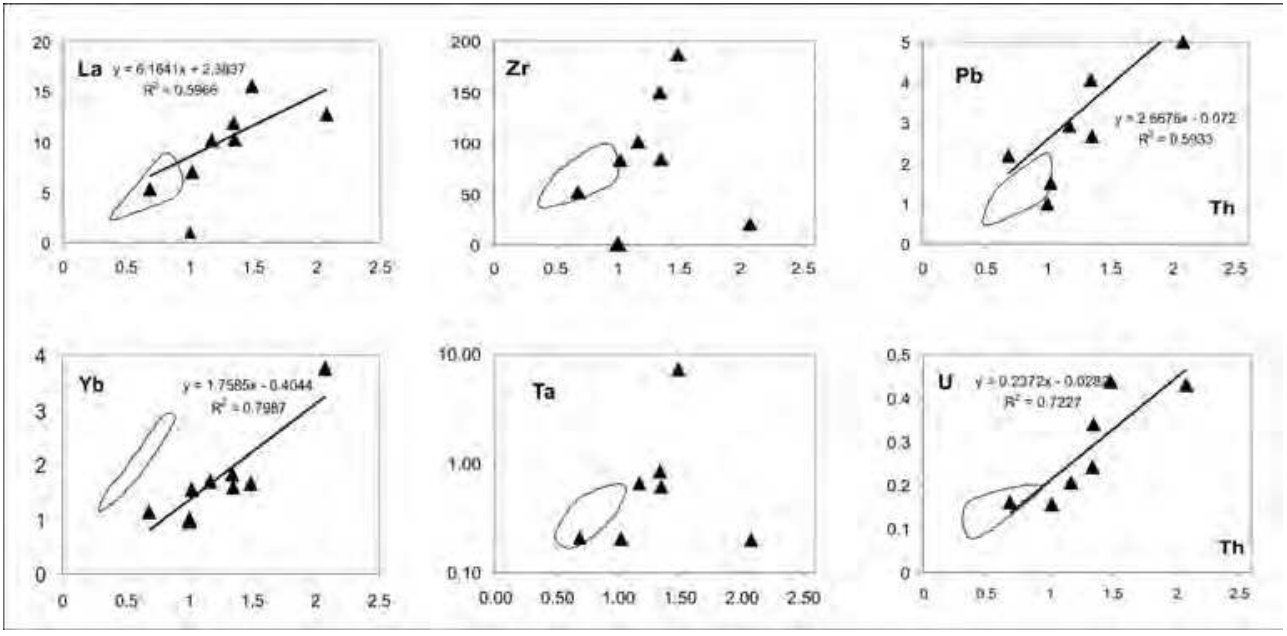

Fig. 8. Correlation between lithophile elements in the dolerites of the Schirmacher Oasis. The fields show lithophile element variations in the basalts of ODP Site 749 according to (Frey et al., 2000).

Figure 9a demonstrates the closeness of characteristic ratios $(\mathrm{Th} / \mathrm{Nb}) \mathrm{n}$ vs $(\mathrm{La} / \mathrm{Nb}) \mathrm{n}$ for magmatic rocks in two provinces of eastern Antarctica. High values (Th/ Nb)n: $15-16$ and $(\mathrm{La} / \mathrm{Nb})$ n: $6-7$ reflect continental nature of their sources. Basing on the data presented in 
Figure $9 \mathrm{~b}$ we can suggest that such source could be sub-continental lithospheric mantle. Values of $\mathrm{Sr} / \mathrm{Pb}$ ratio for alkaline picrites from oasis Jetty and dolerites from Schirmacher Oasis are below NMORB and OIB signatures. Presented MgO content in Jetty Oasis alkaline picrites shows that high $\mathrm{Sr} / \mathrm{Pb}$ and $\mathrm{Nb} / \mathrm{Nb}^{*}$ are not connected with the process of olivine fractionation or accumulation in the course of which $\mathrm{MgO}$ content should regularly decrease but rather reflect the melting of heterogeneous continental mantle.
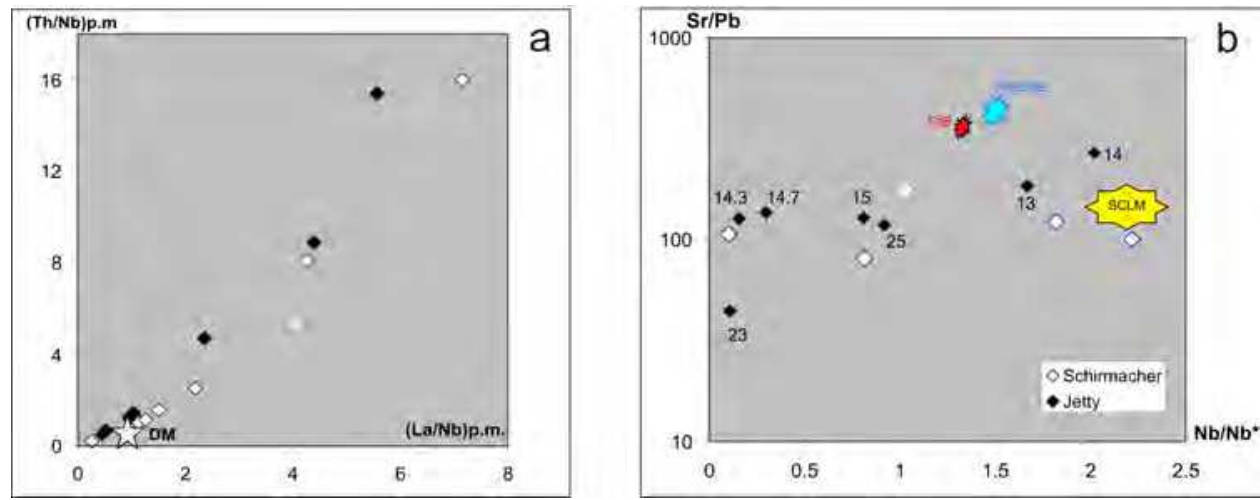

Fig. 9. Diagrams $(\mathrm{Th} / \mathrm{Nb}) \mathrm{n}$ vs $(\mathrm{La} / \mathrm{Nb}) \mathrm{n}(\mathrm{a})$ and $\mathrm{Sr} / \mathrm{Pb}$ vs $\mathrm{Nb} / \mathrm{Nb}^{*}$ (b) for Schirmacher and Jetty oasises. $\mathrm{Nb} / \mathrm{Nb}^{*}$ was defined by Eisele et al. (2002) as $\left[\mathrm{Nb}_{\mathrm{n}} / \sqrt{ }\left(\mathrm{Th}_{\mathrm{n}}{ }^{*} \mathrm{La}_{\mathrm{n}}\right)\right]$ normalized to primitive mantle. SCLM - sub-continental lithospheric mantle (McDonough, 1990), OIB and NMORB signatures according to (Thompson et al., 2007). MgO values are marked for Jetty oasis rocks only.

The isotopic analysis of dolerites from the Schirmacher Oasis (Table 1, Fig. 10) revealed the following strontium radiogenic composition: ${ }^{87 \mathrm{Sr}} / 86 \mathrm{Sr}$ of $0.7045-0.7047$, and lead: ${ }^{208} \mathrm{~Pb} /{ }^{204} \mathrm{~Pb}$ of $37.98-38.2$ and $207 \mathrm{~Pb} / 204 \mathrm{~Pb}$ of $15.45-15.52$. The relatively high $206 \mathrm{~Pb} /{ }^{204} \mathrm{~Pb}$ (17.9-18.2) and low ${ }^{143} \mathrm{Nd} /{ }^{144} \mathrm{Nd}$ values $(0.51275-0.51255)$ also indicate the enrichment of the dolerite source compared with the depleted oceanic mantle (Hauri et al., 1994). Two samples from our collection (47133-1 and 47201-4) are strongly enriched in radiogenic strontium: their ${ }^{87} \mathrm{Sr} / 86 \mathrm{Sr}$ ratios are 0.7099 and 0.7120 , respectively. Dolerite sample $47201-4$ is a strongly altered variety and shows a negative $\mathrm{Zr}-\mathrm{Hf}$ anomaly (Figs. 7 and 8). This sample was not used for the construction of correlation diagrams. It is important that the isotopic compositions of basic rocks from the Schirmacher Oasis are identical to the composition of tholeiites from the Afanasy Nikitin Rise and ODP Site 749. On the other hand, they are significantly different from the tholeiites of the $39^{\circ}-40^{\circ} \mathrm{W}$ anomaly of the Southwest Indian Ridge and anomalous olivine tholeiites from the base of the Afanasy Nikitin Rise, which have low values of $206 \mathrm{~Pb} /{ }^{204} \mathrm{~Pb}(17.2-17.6)$ and ${ }^{143} \mathrm{Nd} /{ }^{144} \mathrm{Nd}(0.5123-0.5124)$ and high values

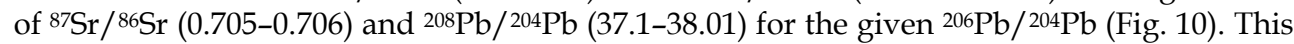
is typical for EM-I enriched mantle sources (Hauri et al., 1994). In general, the isotope characteristics of enriched magmas from DML and the Schirmacher Oasis are similar to those of basalts derived from the Kerguelen plume, but are significantly different from the composition of enriched magmas from the North Atlantic, which are also related to plume activity (Sushchevskaya et al., 2005).

Figure 10 presents isotope data for the rocks connected with Karoo-Maud plume (Dronning Maud Land, Schirmacher) and Kerguelen plume (basalts of Afanasy Nikitin Rise and drill 
holes 749,747) and also Jetty Oasis alkaline picrites. On the base of these diagrams we should mark put the following: 1) In spite of the closeness of enrichment character of plume magmas, for the basalts from Schirmacher Oasis there are not noted the presence of depleted types which are found within Dronning Maud Land (Riley et al., 2005). They are especially well traced in Sr-Nd isotope diagram (Fig. 10c). By isotope data the Schirmacher Oasis magmas are more homogeneous and for them the enriched component with low ${ }^{206} \mathrm{~Pb} /{ }^{204} \mathrm{~Pb}$ and high ${ }^{87} \mathrm{Sr} /{ }^{86} \mathrm{Sr}$ is not determined but it is fixed in some basalts of Dronning Maud Land, Afanasy Nikitin Rise and in drill-hole 747 of Kerguelen Plateau. 2) Enriched component revealed in basalts of Schirmacher Oasis differs, perhaps, insignificantly from the component of DML with lower values of ${ }^{208 \mathrm{~Pb}} /{ }^{204} \mathrm{~Pb},{ }^{207 \mathrm{~Pb}} /{ }^{204} \mathrm{~Pb}$ at the given ${ }^{206 \mathrm{~Pb}} /{ }^{204} \mathrm{~Pb}$ and higher ${ }^{87} \mathrm{Sr} /{ }^{86} \mathrm{Sr}$ (the most altered samples are not considered). It should be marked, that alkaline picrites of Jetty Oasis which reflect the features of the East Antarctic continental mantle are not enriched in radiogenic $\mathrm{Sr}$ at the same degree as the basalts of the Schirmacher Oasis. They are close in isotope composition to the enriched component of the Schirmacher Oasis and DML basites but differ by considerable enrichment in radiogenic ${ }^{208} \mathrm{~Pb}$. At the same time, Ferrar lamproites (or ultramafic lamprophyres, Riley et al., 2003) connected with distribution of Karoo-Maud plume to the south along Transantartic mountains are even more enriched in radiogenic lead which reflects the specific character of lithospheric mantle in this region.

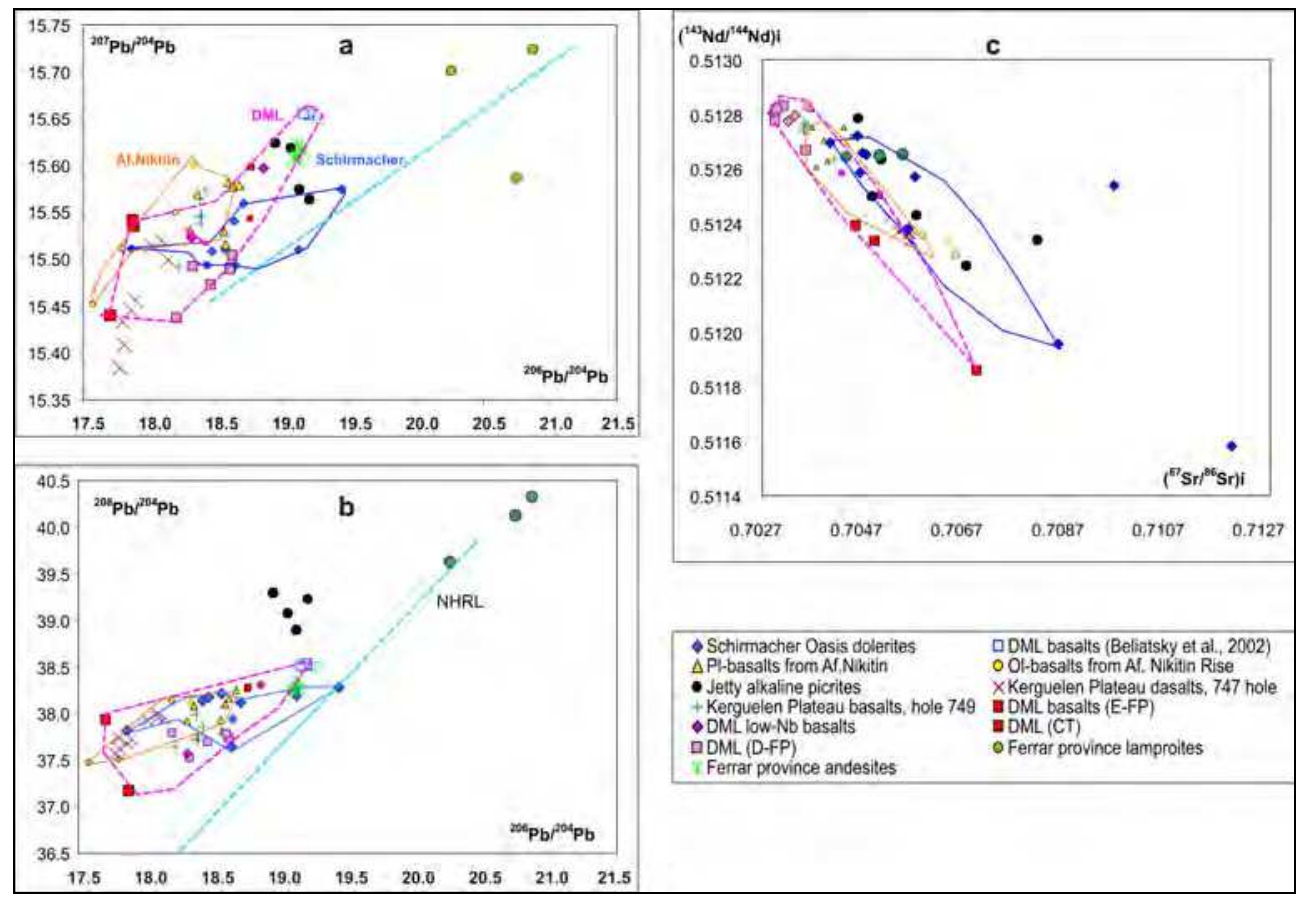

Fig. 10. Comparative isotope $(\mathrm{Pb}, \mathrm{Sr}, \mathrm{Nd}$ ) characteristics of Karoo-Maud and Kerguelen plume-related magmatic rocks, Jetty Oasis alkaline picrites and Ferrar province andesites and lamproites (Table 1, 2; Antonini et al., 1999; Belyatsky et al., 2002; Borisova et al., 2001; Frey et al., 2000; Heinonen et al., 2010; Sushchevskaya et al., 1996; Sushchevskaya et al., 2003). Chemical types of DML basalts (low-Nb, D-FP, E-FP, CT) refer to (Heinonen et al., 2010). 


\section{Discussion}

The geochemical data for the basic rocks of the Schirmacher Oasis, which is located to the east of the previously investigated occurrences of plume magmatism, provide new insight into the spatial temporal evolution of this plume. The area of occurrence of basaltic lavas related to the arrival of the Karoo-Maud plume beneath the lithosphere of Central Gondwanaland is up to $2000 \mathrm{~km}$ in diameter (Elliot et al., 1997; Elliot \& Fleming, 2000; Leitchenkov \& Masolov, 1997), which is well consistent with the typical size of superplume heads projected to the surface (White \& McKenzie, 1989). Perhaps, the emplacement of the plume and subsequent thermal erosion of the lithosphere under the influence of laterally flowing plume material triggered the breakup of Gondwana: Antarctica separation from the southern Africa was about 165-155 Ma (Martin \& Hartnady, 1986). Nevertheless, it should be noted that the Karoo-Maud plume probably was different in some respects from what is considered to be a typical mantle plume (Courtillot et al., 2003): the volume of magmatic material supplied to the surface is minor, no higher than $60000 \mathrm{~km}^{3}$, even if the partly overlain volcanics of the Karoo basin with accompanying dikes, sills, and small intrusions are accounted for; the plume-lithosphere interaction occurred in several stages over a long time interval, in contrast to the short-term (1-4 Ma) magmatism that usually accompanies the penetration of mantle plumes into the lithosphere (White \& McKenzie, 1989). The investigation of the character of flood basalt magmatism in Antarctica, which was performed within the MAMOG Project (Leat et al., 2007), confirmed that it lasted for at least 20-30 Ma, when a series of dikes and flows were formed around the plume center over an area of about $145000 \mathrm{~km}^{2}$ along the Antarctic coast (DML). The eastward spreading of the Karoo-Maud plume can be indirectly supported by the existence of a large basic intrusion, which extends along the DML coast and is marked by a high-amplitude ( $\times 100$ nT) magnetic anomaly (Golynsky et al., 2002, 2006).

Figure 11 shows the possible eastward direction of plume head spreading in the sublithospheric mantle of Gondwana at 130 Ma. During that time, the activity of the Kerguelen plume began within the already existing Indian Ocean and affected a region from the western margin of Australia to India. Its activity was manifested 40-50 Ma after the maximum magmatic activity related to the Karoo - Maud plume (Coffin et al., 2002; Frey et al., 1996; Mahoney et al., 1995). It is interesting that the activity of the Etendeka-Parana plume, which preceded and accompanied the opening of the South Atlantic, began at the west of the Karoo-Maud plume, in South America and Central Africa at about $130 \mathrm{Ma}$ (Deckart et al., 1998). The lead isotopic ratios of basalts from the Schirmacher Oasis are different from those of the DML basalts, which have even more radiogenic values of ${ }^{206} \mathrm{~Pb} /{ }^{204} \mathrm{~Pb}$ ratios, up to $18.7-18.8$. Nonetheless, in the lead isotope diagram, all these rocks plot along a common trend, which extends from the relatively depleted dolerites of the Schirmacher Oasis to the more enriched basalts of western DML (Fig. 10) (Belyatsky et al., 2006) and the Transantarctic Mountains, which underwent extensive crustal contamination (Elliot et al., 1999). This diagram also shows the isotopic compositions of ancient Proterozoic anorthosite dikes recalculated to the emplacement age of Mesozoic dolerites. It is clearly seen that they plot in the field of the Mesozoic basalts of Antarctica. As was noted above, the ancient dikes often spatially associate with plume related dikes and have similar strike and dip angles, at least in the Schirmacher Oasis. 


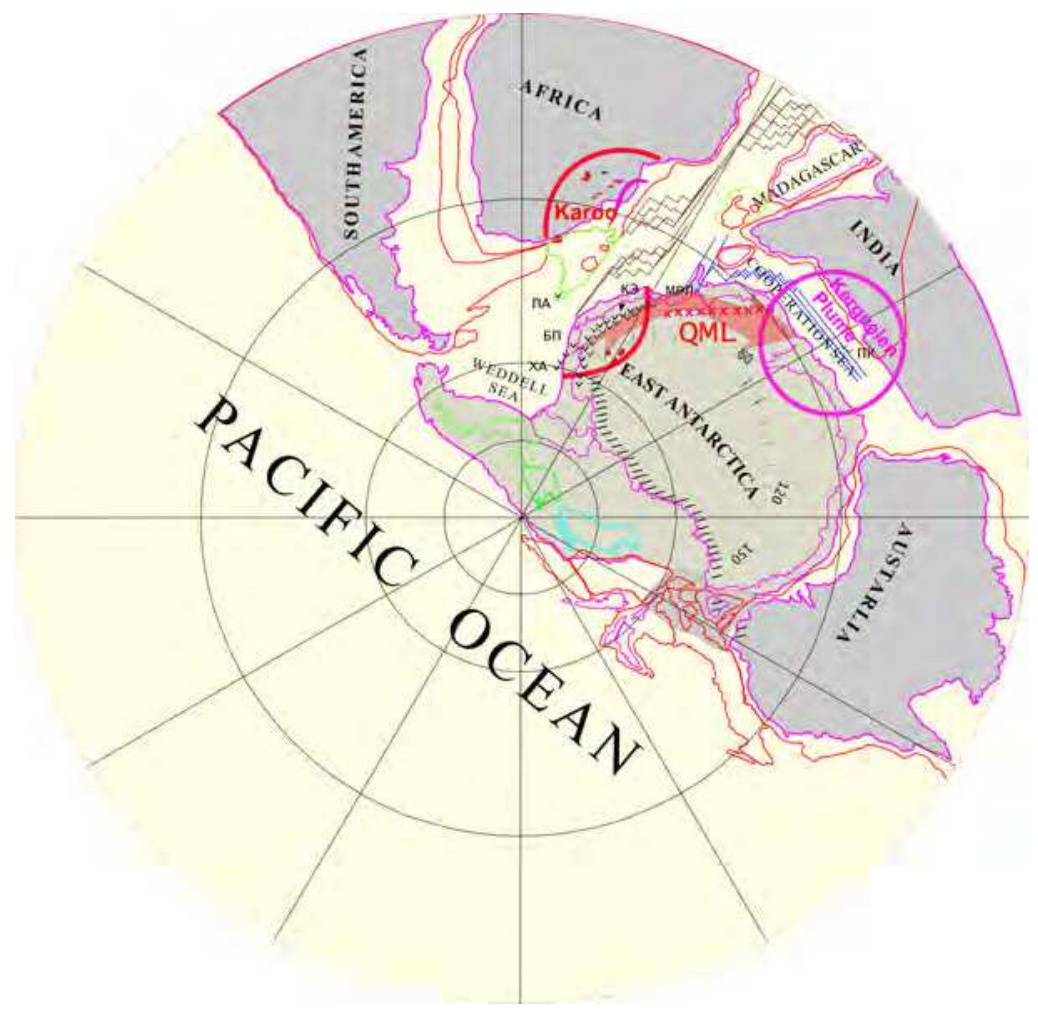

Fig. 11. Eastward propagation of the Karoo-Maud plume according to the reconstruction (Leitchenkov et al., 2003) for $130 \mathrm{Ma}$. The symbols are: oblique crosses - area of basic intrusion distribution within QML according magnetic data, slashed area - Ferrar dolerites on the geological data, tick marks - volcanic complexes (ridges, plateaus), ПA - Agulhas Plateau, БП - Polarstern Bank, XА - Andenes Escarpment, КЭ - Explora complex, ПК Kerguelen Plateau, МРЛ - Riiser-Larsen Sea. The brown and blue lines within ocean display spreading centers, red circles outline plume-related magmatism (suggested).

The spreading of Mesozoic plume magmas evidently occurred mainly along highly permeable weakened zones in the lithosphere (Leitch et al., 1998) and the ancient dike zones could serve as magma conduits. Such a process of plume melt penetration along the zones of ancient dikes was also typical for the Karoo plume distribution in the southeastern part of the African continent at 180-173 Ma (Jourdan et al., 2004, 2006).

The inherited old zircon grains (500-850 Ma) discovered in the dolerites of the Schirmacher Oasis could reflect the contamination of higher temperature Jurassic tholeiitic magmas by the material (zircons) of ancient andesites and/or enclosing metamorphic rocks (Belyatsky et al., 2007). Salient features of the Karoo-Maud plume magmatism in Antarctica are the presence of high-magnesium volcanics and the wide occurrence of dolerite dikes and sills and olivine-rich gabbroid intrusions. Many of the dolerites are chemically similar to slightly enriched tholeiites (Luttinen \& Furnes, 2000), which suggests that the plume magma source was similar to the depleted oceanic mantle (Fig. 12). The plagioclase $\mathrm{K}-\mathrm{Ar}$ age of basaltic lavas from the Vestfjella Mountains is $180 \mathrm{Ma}$, which is very close to the ages of the basalts 
of the Kirwanveggen (Luttinen \& Furnes, 2000) and mafic dikes and flows of southeastern Africa (183 $\pm 1 \mathrm{Ma}$ ) (Duncan et al., 1997; Jourdan et al., 2006). The Sm-Nd mineral (pyroxene and plagioclase) and bulk rock isochron age of the dolerites of the Schirmacher Oasis is $171 \pm 24 \mathrm{Ma}$, which coincides within the uncertainty with the age of the Jurassic magmatism of DML and southeastern Africa (Belyatsky et al., 2006).

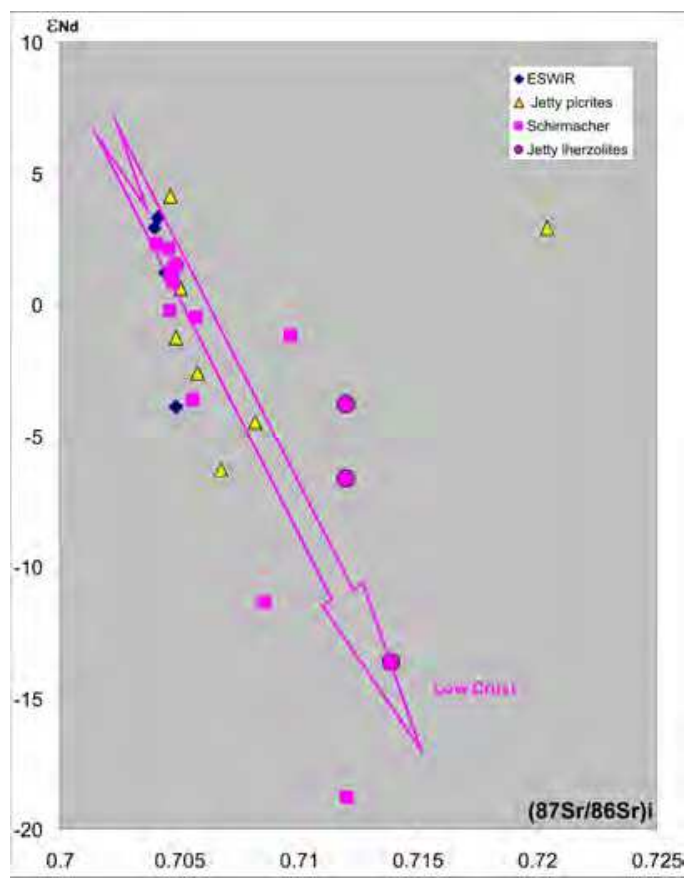

Fig. 12. Isotope characteristics of Schirmacher Oasis dolerites, Jetty Oasis alkaline picrites and mantle lherzolite inclusions and SWIR tholeiites as well reflect mainly the effect of lower crust contamination (enriched crustal component) of Antarctic plume primary melts. The most isotope enriched sample 47201-4 (Schirmacher Oasis) is a highly carbonatized and potassium enriched altered dolerite.

Thus, based on the geochemical, isotopic, and petrological similarity and simultaneous formation, the Mesozoic basic magmatism of the Schirmacher Oasis can be interpreted with a high degree of certainty as a derivative of the activity of the Karoo-Maud mantle plume (by analogy with the western DML of Antarctica and the Karoo province of the southeastern Africa). The youngest Mesozoic-Cenozoic occurrences of intraplate magmatism (alkaline ultrabasic intrusions, kimberlite sills and dikes, and leucite basalts of the Manning massif, Fig. 6) in East Antarctica are localized at the region of the Prince Charles Mountains (McRobertson Land) and Princess Elizabeth Coast (alkaline volcanics of Gaussberg), 3 000-4 $000 \mathrm{~km}$ east of DML. Their formation is supposedly related to the activation of the sublithospheric mantle of Antarctica under the influence of the Kerguelen plume, whereas the emplacement of the alkaline ultrabasic dikes and sills of the Jetty Oasis is directly correlated with the initial stages of Kerguelen plume interaction with the lithosphere of Antarctica at 130-105 Ma (Laiba et al., 1987). 


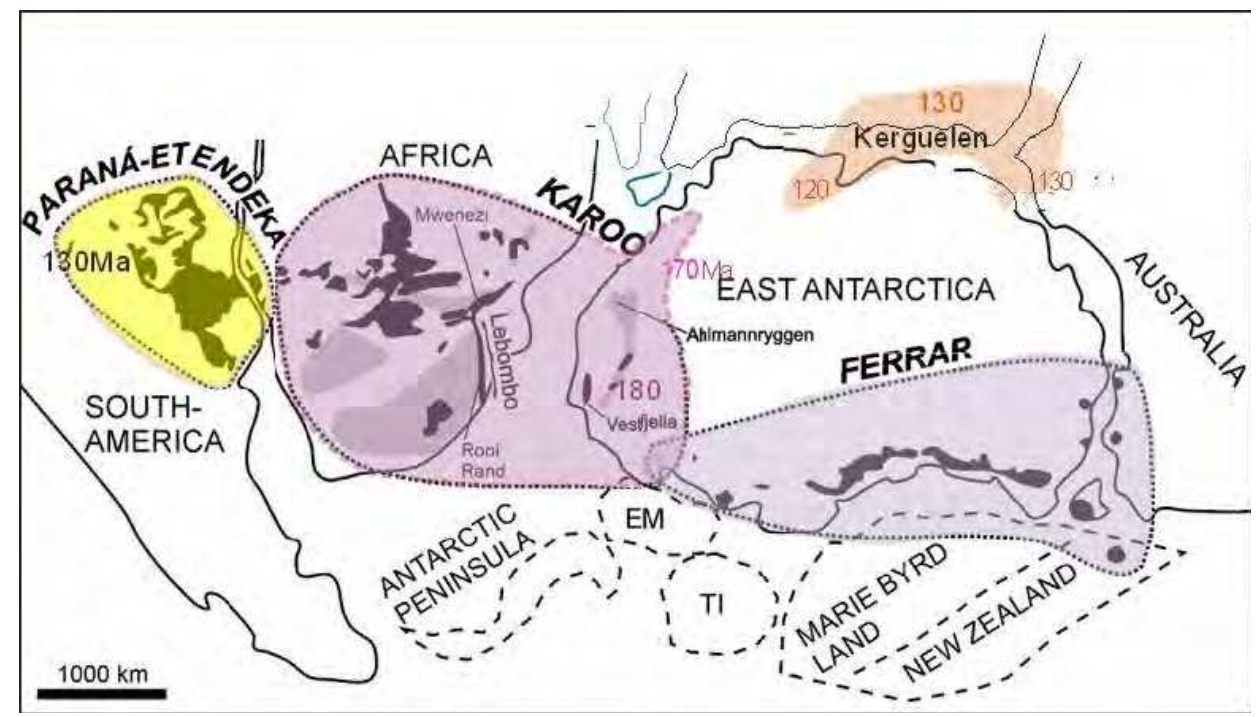

Fig. 13. Distribution of Mesozoic CFBs in reconstructed Gondwana supercontinent at the age about $170 \mathrm{Ma}$ ago. In the case of the Karoo province, the known extent of intrusive equivalents (found outside CFBs) is also shown. The ages of main phases of magmatic activities of Karoo and Kerguelen plumes are pointed in Ma. EM=Ellsworth-Whitmore Mountains, TI=Thurston Island. Reconstruction modified after Heinonen et al. (2010), Hergt et al. (1991), Kent (1991), Storey et al. (1992), Segev (2002), Leat et al. (2006), and Jourdan et al. (2004).

Numerous investigations and reconstructions of the influence of the Kerguelen plume on the lithosphere of Antarctica and India suggest that the plume head spreads in the northeastern direction (Coffin et al., 2002; Frey et al., 1996, 2000; Kent, 1991; Mahoney et al., 1995). The possible early occurrence of the plume at $130 \mathrm{Ma}$ is reconstructed from the magmatism of continental margins (Fig. 13). This concerns primarily the Bunbury Province of the southwestern coast of Australia and the magmatism of the eastern coast of India (Rajmahal traps). On the other hand, considerable areas of igneous rocks related to the Kerguelen plume are currently located below the sea level and detected only on the basis of seismic data for the northern Bay of Bengal and the Naturaliste Plateau (Kent, 1991). It is supposed that the Kerguelen plume also extended far to the northeast (i.e., it differed from the classical concentrically isometric shape during emplacement in the lithosphere).

Figure 13 shows the area of Kerguelen plume development during the early stages of ocean opening, which were accompanied by the extensive occurrence of enriched tholeiites. The distribution of enriched basalts with high (La/Sm)n (Sushchevskaya et al., 1998) reflects the possible consequences of plume activity (formation of enriched tholeiitic magmas and formation of large rises at a fossil spreading zone). The depleted compositions of igneous rocks exposed at the flanks indirectly support the emplacement of the Kerguelen plume in the already open ocean.

The Karoo-Maud superplume is probably an example of deep plumes ascending from the core-mantle boundary. Its penetration into the upper parts of the lithosphere resulted in the breakup of Gondwana and the separation of Africa from Antarctica. Then, for a considerable time (about $40 \mathrm{Ma}$ ) it could flow laterally along preexisting boundaries in the upper parts of 
the lithosphere, which caused the formation of the younger Parana-Etendeka and Kerguelen mantle plumes. The formation of two large igneous provinces, Parana-Etendeka in the Atlantic and Kerguelen in the Indian Ocean, significantly influenced oceanic magmatism and resulted primarily in the appearance of geochemical anomalies within mid-ocean ridges. The spreading of plume material along the weakened zones of Gondwana to the south (Ferrar dolerites in the Transantarctic Mountains) and east (from western DML to the Prince Charles Mountains) of Antarctica reflects possible deep plume motions, which probably occurred at different levels of the lithosphere and sublithospheric mantle (Fig. 11). Geological and geophysical data for the basement of the basins of the Cosmonaut, Cooperation, and Davis seas suggest moderate spreading rates at the early stages of ocean opening (Hinz \& Krause, 1982; Leitchenkov et al., 2006). The early stages of this process produced volcanic rises in the western part of the Riiser-Larsen Sea (Astrid Ridge), in the Lazarev Sea, in the southeastern Weddell Sea (Leitchenkov \& Guseva, 2006), and in the southeastern Davis Sea (Bruce Bank, in the east of the Kerguelen Plateau). These structural and tectonic features could be related to the influence of the Karoo-Maud superplume on the formation of the oceanic crust in this region, if one supposes its eastward spreading up to the old deep rift zone (region of the LambertAmery Glacier and Prydz Bay), which inherited to some extent the structures of Paleozoic grabens, was filled with sediments up to $10 \mathrm{~km}$ thick (Fedorov et al., 1982; Leitchenkov et al., 1999) and separated different blocks of the continental lithosphere of Antarctica (probably of different thickness) to the west and east of it. The further lateral spreading of the plume occurred towards the already existing ocean basin, which resulted in the formation along the proto-Southeast Indian Ridge of the Conrad, Kerguelen, and Afanasy Nikitin volcanic rises and the Southeast Indian Ridge (Sushchevskaya et al., 1998, 2003). Blocks of metamorphosed old subcontinental mantle could be retained within and near the spreading zone and subsequently involved into melting processes (Fig. 12).

Geophysical data obtained by Russian expeditions in 2003-2004 demonstrated that, before the beginning of the Australia-Antarctica breakup, a continental block existed at the margin of the Australia-Antarctica continent and was subsequently divided by the spreading zone into the Bruce Bank (remaining near Antarctica) and the Naturaliste Plateau (Leitchenkov \& Guseva, 2006). The layered basement of the Bruce Bank is a pile of volcanic rocks, up to 3.5 $\mathrm{km}$ thick, underlain by the thinned continental crust (Leitchenkov \& Guseva, 2006). The results of deep-sea drilling in the Elan Bank in the western spur of the Kerguelen Plateau also suggest its continental origin (Ingle et al., 2002). Thus, the complex formation of an ancient spreading zone during the initial stages of ocean opening resulted in the detachment of continental lithospheric blocks of different size, which could significantly affect the geochemical character of tholeiitic magmatism within rift zones. This effect is observed in volcanic rises, such as the Kerguelen Plateau, Afanasy Nikitin Plateau, and Ninetyeast Ridge. The eastward propagation of plume magmatism in Antarctica along the ancient collision zone reflects the processes that occurred in the apical part of the plume at about 180-110 Ma. The established geochemical similarity between the basalts of the continental margin of eastern India (Rajmahal traps) and Southwestern Australia (Bunbury basalts) and the tholeiites of the Kerguelen Plateau implies the assimilation of the ancient continental crust of Gondwanaland by the basaltic melts (Ingle et al., 2002). The isotopic systematics of the dolerites of the Schirmacher Oasis suggests the following average initial isotopic ratios for their primary magmas: ${ }^{207 \mathrm{~Pb}} /{ }^{204} \mathrm{~Pb}=15.502,208 \mathrm{~Pb} / 204 \mathrm{~Pb}=38.114,{ }^{206} \mathrm{~Pb} / 204 \mathrm{~Pb}=18.026$, ${ }^{87} \mathrm{Sr} /{ }^{66} \mathrm{Sr}=0.70568,{ }^{143} \mathrm{Nd} /{ }^{144} \mathrm{Nd}=0.512629$ (Fig. 12). Similar isotopic ratios are characteristic of the tholeiites of the Afanasy Nikitin Rise (Borisova et al., 2001; Sushchevskaya et al., 
1996), which were formed 90 Ma near the proto-Southeast Indian Ridge, and of the $115 \mathrm{Ma}$ tholeiites of the central part of the Kerguelen Island (Frey et al., 2002).

The problem of the deep origin of hotspots (and low-velocity zones) in the Earth's shells has acquired special significance, because it has a direct influence on the possible spatial movement (both vertical and horizontal) of convective mantle flows (Burov et al., 2007). For instance, Pushcharovskii (Pushcharovskii \& Pushcharovskii, 1999) emphasized that the Earth's shells, including the upper, middle, and lower mantle, with boundaries at depths of $670-900 \mathrm{~km}, 1700-2000 \mathrm{~km}$, and $2900 \mathrm{~km}$, have heterogeneities of various scales, which reflect possible lateral movement of materials. Ruzhentsev with colleagues (Ruzhentsev et al., 1999) investigated the deep structure of the India-Atlantic segment of the Earth using the deep seismic tomography data and concluded that heated zones exist in the mantle at different depths. These zones are not traced into deeper levels which suggests that some of them are detached from their roots and have a lateral distribution (Ruzhentsev et al., 1999). According to recent data (Class \& le Roex, 2008), the possible horizontal movement of sublithospheric flows from beneath Africa over considerable distances can be exemplified by the formation of peculiar enriched magmas in the central part of the Walvis Ridge.

\section{Conclusions}

The investigation of the Mesozoic (about $170 \mathrm{Ma}$ ) basaltic magmatism of the Schirmacher Oasis showed that the basalts and dolerites are petrologically identical to the previously studied rocks of western Dronning Maud Land (Vestfjella Mountains region), which are interpreted as the manifestation of the Karoo-Maud plume in Antarctica. The spatial distribution of the dikes indicates the eastward spreading of the plume material from DML to the Schirmacher Oasis within at least $10 \mathrm{Ma}$ (up to $\sim 35 \mathrm{Ma}$, taking into account the uncertainty of age determination). On the other hand, the considerable duration and multistage character of plume magmatism related to the activity of the Karoo-Maud plume in Antarctica and Africa (Leat et al., 2007; Luttinen et al., 2002) may indicate that the Mesozoic dikes of the oasis correspond to a single stage of plume magmatism. In such a case, the rate of eastward plume propagation can be considered only as a rough estimate, and the time of $10 \mathrm{Ma}$, as the upper limit.

The geochemical characteristics (relatively radiogenic $\mathrm{Sr}$ and unradiogenic $\mathrm{Nd}$ isotope composition, high $\mathrm{Th} / \mathrm{Nb}$ and $\mathrm{Ta} / \mathrm{Nb}$ ratios) of Schirmacher Oasis magmas indicate crustal contamination, which occurred during plume ascent and lateral spreading. The magmas of the initial stage of plume activity (western DML region) appeared to be the most contaminated. A peculiar feature of the opening of the Indian Ocean, which was triggered by the influence of the Karoo-Maud plume, is its occurrence in the presence of nonspreading blocks of varying thickness, such as the Elan Bank in the central part of the Kerguelen Plateau, and it was accompanied by the formation of intraplate volcanic rises, which were detected in the seafloor relief around Antarctica. The geochemical characteristics of some of these highs (Afanasy Nikitin, Kerguelen, Naturaliste, and Ninetyeast Ridge) as demonstrated by (Borisova et al., 2001) were mainly affected by crustal assimilation processes. The identical geochemical characteristics of the Mesozoic magmas of the Schirmacher Oasis, the lavas of the Afanasy Nikitin Rise, and the rocks of the central Kerguelen Plateau (ODP Site 749) suggest that the enrichment of all these magmas was related to the old continental rocks of the Gondwanaland. The magmatism that occurred 40 
Ma after the main phase of the Karoo volcanism at the margins of the adjoining continents of Australia (Bunbury basalts) and India (Rajmahal traps) could be initiated by the KarooMaud plume, which propagated along the developing spreading zone and subsequently moved toward the Kerguelen Plateau, where it occurs currently as an active hotspot.

\section{Acknowledgment}

This work was financially supported by the Russian Foundation for Basic Research, project no. 09-05-00256. Editor Dr. Francesco Stoppa is sincerely thanked for reviewing and constructive comments that helped to improve the quality of the paper.

\section{References}

Andronikov, A. V. \& Egorov, L.S. (1993). Mesozoic alkaline-ultrabasic magmatism of Jetty Peninsula. In: Gondwana Eight: Assembly, Evolution and Dispersal. Findlay, R.H., Unrug, R., Banks, M.R. \& Veevers, J.J. (eds). Balkema. Rotterdam. pp. 547-557.

Andronikov, A.V. \& Foley, S.F. (2001). Trace element and Nd-Sr isotopic composition of ultramafic lamprophyres from the East Antarctic Beaver Lake area. Chemical Geology, Vol.175, pp. 291-305.

Antonini, P., Piccirillo, E.M., Petrini, R. \& et al. (1999). Enriched mantle - Dupal signature in the genesis of the Jurassic tholeiites from Prince Albert Mountains (Victoria LandAntarctica). Contributions to Mineralogy and Petrology, Vol.136, pp. 1-19.

Belyatsky, B.V., Prasolov, E.M., Sushchevskaya, N.M. \& et al. (2002). Specific Features of the Isotopic Composition of Jurassic Magmas in the Dronning Maud Land, Antarctica. Doklady Earth Sciences, Vol.386, pp. 855-858.

Belyatsky, B.V., Sushchevskaya, N.M., Leichenkov, G.L. \& et al., (2006). Magmatism of the Karoo-Maud Superplume in the Schirmacher Oasis, East Antarctica. Doklady Earth Sciences, Vol.406, pp. 128- 131.

Belyatsky, B., Rodionov, N., Savva, E. \& Leitchenkov, G. (2007). Zircons from mafic dykes as a tool for understanding of composition and structure of continental crust: on the example of Mesozoic olivine dolerite dykes. Schirmacher oasis. Antarctica. Geophysical Research Abstracts, Vol.9, 10509. SRef-ID: 1607-7962/gra/EGU2007-A10509.

Borisova, A.Yu., Nikulin, V.V., Belyatskii, B.V. \& et al. (1996). Late Alkaline Lavas of the Ob and Lena Seamounts (Conrad Rise, Indian Ocean): Geochemistry and Characteristics of Mantle Sources. Geochemistry International, Vol.34, pp. 503-517.

Borisova, A.Yu., Belyatsky, B.V., Portnyagin, M.V. \& Suschevskaya, N.M. (2001). Petrogenesis of an olivine-phyric basalts from the Aphanasey Nikitin Rise: evidence for contamination by cratonic lower continental crust. Journal of Petrology, Vol.42, pp. 277-319.

Brewer, T.S., Rex, D., Guise, P.G. \& Hawkesworth, C.J. (1996). Geochronology of Mesozoic tholeiitic magmatism in Antarctica: implications for the development of the failed Weddell Sea rift system. In: Weddell Sea: Tectonics and Gondwana break-up. Storey, B., King, E. \& Livermore, R. (eds). 1996. Geol. Soc. Spec. Publ., Vol.108, pp. 45-62.

Burov, E., Guillou-Frottier, L.,. d'Acremont, E. \& et al. (2007). Plume head - lithosphere interactions near intra-continental plate bounadries. Tectonophysics, Vol.434, No.1-4, pp. 15-38. 
Chase, C.G. \& Patchett, P.J. (1988). Stored mafic/ultramafic crust and early Archean mantle depletion. Earth and Planetary Science Letters, Vol.91, pp. 66-72.

Christensen, U.R. \& Hofmann, A.W. (1994). Segregation of subducted oceanic crust in the convecting mantle. Journal of Geophysical Research, Vol.99 (B10), pp. 19867-19884.

Class, C. \& le Roex, A.P. (2008). Continental material in the shallow oceanic mantle-How does it get there? Geology, Vol.34, No.3, pp. 129-132.

Coffin, M.F., Pringle, M.S., Duncan, R.A. \& et al. (2002). Kerguelen hotspot magma output since 130 Ma. Journal of Petrology, Vol.43, pp. 1121-1139.

Courtillot, V., Davaille, A., Besse, J. \& Stock, J. (2003). Three distinct types of hotspots in the Earth's mantle. Earth and Planetary Science Letters, Vol.205, pp. 295-308.

Curray, J.R. \& Munasinghe, T. (1991). Origin of the Rajmahal traps and the $85^{\circ} \mathrm{E}$ Ridge: preliminary reconstructions of the trace of the Crozet hotspot. Geology, Vol.19, pp. 1237-1240.

Dalziel, I.W.D., Lawver, L.A. \& Murphy, J.B. (2000). Plumes, orogenesis, and supercontinental fragmentation. Earth and Planetary Science Letters, Vol.178, pp. 1-11.

Deckart, K., Feraund, G., Marques, L.S. \& Bertrand, H. (1998). New time constraints on dyke swarms related to the Parana-Etendeka magmatic province and subsequent South Atlantic opening, Southeastern Brazil. Journal of Volcanological and Geothermal Researches, Vol.80, No.1-2, pp. 67-83.

Doucet, S., Scoates, J.S., Weis, D. \& Giret, A. (2005). Constraining the components of the Kerguelen mantle plume: a Hf-Pb-Sr-Nd isotopic study of picrites and high-MgO basalts from the Kerguelen Archipelago. Geochem. Geophys. Geosys., Vol. 6, No.4, Q04007. doi: 10.1029/2004GC000806.

Duncan, R.A., Hooper, P.R., Rehacek, J. et al. (1997). The timing and duration of the Karoo igneous event. southern Gondwana. Journal of Geophysical Research, V.102 (B8), pp. 18127-18138.

Elliot, D.H., Fleming, T.H., Kyle, P.R. \& Foland, K.A. (1999). Long-distance transport of magmas in the Jurassic Ferrar Large Igneous Province, Antarctica. Earth and Planetary Science Letters, Vol.167, pp. 89-104.

Elliot, D.H. \& Fleming, T.H. (2000). Weddell triple junction: the principal focus of Ferrar and Karoo magmatism during initial break-up of Gondwana. Geology, Vol.28, pp. 539542.

Fedorov, L.V., Ravich, M.G. \& Hofmann, J. (1982). Geologic comparison of southeastern Peninsular India and Sri Lanka with a part of East Antarctica (Enderby Land. MacRobertson Land. and Princess Elizabeth Land). in: Antarctic Geoscience. Craddock, C. (ed). The University of Wisconsin Press. Madison. Wisconsin. pp. 7378.

Foley, S.F., Andronikov, A.V. \& Melzer, S. (2001). Petrology of ultramafic lamprophyres from the Beaver Lake area of Eastern Antarctica and their relation to the breakup of Gondwanaland. Mineralogy and Petrology. V.74. pp. 361-384.

Foley, S.F., Andronikov, A.V., Jacob, D.E. \& Melzer, S. (2006). Evidence from Antarctic mantle peridotite xenoliths for changes in mineralogy, geochemistry and geothermal gradients beneath a developing rift. Geochemical et Cosmochemical Acta, Vol.70, pp. 3096-3120.

Frey, F.A., McNaughton, N.J., Nelson, D.R. \& et al. (1996). Petrogenesis of the Bunbary basalt. western Australia: ineraction between the Kerguelen plume and Gondwana lithosphere? Earth Planetary Science Letters, Vol.144, pp. 163-183. 
Frey, F.A., Coffin, M.F. \& 18 others. (2000). Origin and evolution of a submarine large igneous province: the Kerguelen Plateau and Broken Ridge, southern Indian Ocean. Earth and Planetary Science Letters, Vol.176, pp. 73-89.

Frey, F.A., Nicolaysen, K., Kubit, B.K., \& et al. (2002). Flood basalt from Mount Tourmente in the Central Kerguelen Archipelago: the change from transitional to alkaline basalt at 25 Ma. Journal of Petrology, Vol.43, No.7, pp. 1367-1387.

Golynsky, A.V., Alyavdin, S.V., Masolov, V.N. \& et al. (2002). The composite magnetic anomaly map of the East Antarctic. Tectonophysics, Vol.347, pp. 109-120.

Golynsky, A.V., Chiappini, M., Damaske, D. \& et al. (2006). ADMAP - a digital magnetic anomaly map of the Antarctic. in: Antarctica - contributions to global Earth Sciences. Futerer, D.K., Damaske, D., Kleinschmidt, G., Miller, H. \& Tessensohn, F. (eds). Springer-Verlag. Berlin. pp. 109-116.

Harris, C., Marsh, J.S., Duncan, A.R. \& Erlank, A.J. (1990). Petrogenesis of the Kirwan basalts of Dronning Maud Land. Antarctica. Journal of Petrology, Vol.31, pp. 341-369.

Hauri, E.H., Whitehead, J.A. \& Hart, S.R. (1994). Fluid dynamic and geochemical aspects of entrainment in mantle plumes. Journal of Geophysical Research, Vol.99, pp. 2427524300.

Heinonen, J.S., Carlson, R.W. \& Luttinen, A.V. (2010). Isotopic (Sr, Nd, Pb and Os) composition of highly magnesian dikes of Vestfjella, western Dronning Maud Land, Antarctica: a key to the origins of the Jurassic Karoo large igneous province? Chemical Geology, Vol.277, pp. 227-244.

Hergt, J.M., Peate, D.W. \& Hawkesworth, C.J. (1991). The petrogenesis of Mesozoic Gondwana low-Ti flood basalts. Earth and Planetary Science Letters, Vol.105, pp. 134148.

Hinz, K. \& Krause, W. (1982). The continental margin of Queen Maud Land. In: Antarctica seismic sequences. structural elements and geological developments. Geologisches Jahrbuch, Vol.E23, pp. 17-41.

Hoch, M. \& Tobschall, H.J. (1998). Minettes from Schirmacher Oasis. East Antarctica indicators of an enriched mantle source. Antarctic Science, Vol.10, No.4, pp. 476-486.

Hoch, M., Rehkamper, M. \& Tobschall, H.J. (2001). Sr, Nd, Pb and O isotopes of minettes from Schirmacher Oasis. East Antarctica: a case of mantle metasomatism involving subducted continental material. Journal of Petrology, Vol.42, No.7, pp. 1387-1400.

Hofmann, A.W. (1988). Chemical differentiation of the Earth: The relationship between mantle, continental crust, and oceanic crust. Earth and Planetary Science Letters, Vol.90, pp. 297-314.

Ingle, S., Weis, D., Scoates, J.S. \& Frey F.A. (2002). Relationship between the early Kerguelen plume and continental flood basalts of the paleo-Eastern Gondwanan margins. Earth and Planetary Science Letters, Vol.197, pp. 35-50.

Jokat, W., Boebel, T.M., Konig, M. \& Meyer, U. (2003). Timing and geometry of early Gondwana breakup. Journal of Geophysical Research, Vol.108 (B9), No.2428, doi:10.1029/2002JB001802.

Jourdan, F., Feraud, G., Bertrand, H. \& et al. (2004). The Karoo triple junction questioned: evidence from Jurassic and Proterozoic ${ }^{40} \mathrm{Ar} /{ }^{39} \mathrm{Ar}$ ages and geochemistry of the giant Okavango dyke swarm (Botswana). Earth and Planetary Science Letters, Vol.222, pp. 989-1006.

Jourdan, F., Feraud, G., Bertrand, H. \& et al. (2005). Karoo large igneous province: brevity. origin. and relation to mass extinction questioned by new ${ }^{40} \mathrm{Ar} /{ }^{39} \mathrm{Ar}$ age data. Geology, Vol.33, No.9, pp. 745-748. doi:10.1130/G21632.1. 
Jourdan, F., Feraud, G., Bertrand, H. \& et al. (2006). Basement control on dyke distribution in Large Igneous Provinces: case study of the Karoo triple junction. Earth and Planetary Science Letters, Vol.241, pp. 307-322.

Kent, R. (1991). Lithospheric uplift in eastern Gondwana: Evidence for a long-lived mantle plume system? Geology, Vol.19. pp. 19-23.

Kent, R.W., Saunders, A.D., Kempton, P.D. \& Ghose, N.C. (1997). Rajmahal basalts. eastern India: mantle sources and melt distribution at a volcanic rifted margin. In: Large igneous provinces: continental. oceanic and planetary flood volcanism. Mahoney, J.J. \& Coffin, M.F. (eds). Geophysical Monograph Series, Vol.100, AGU. Washington DC. pp. 145-182.

Kent, R.W., Pringle, M.S., Mueller, R.D. \& et al. (2002). ${ }^{40} \mathrm{Ar} /{ }^{39} \mathrm{Ar}$ Geochronology of the Rajmahal basalts. India. and their relationship to the Kerguelen plateau. Journal of Petrology, Vol.43, pp. 1141-1153.

Kurinin, R.G., Grinson, A.S. \& Dhun Zhun Yu. (1988). Rift-zone of Lambert Glacier - as possible alkaline-ultramafic province in the East Antarctica. Reports of SU Academy of Sciences, Vol.299, pp. 944-947.

Kurinin, R.G. \& Grikurov, G.E. (1980). Structure of the rift zone of the Lambert glacier. Reports of SAE. Hydrometeoizdat. Leningrad, Vol.70, pp. 75-86.

Laiba, A.A., Vorobiev, D.M., Gonghurov N.A. \& Tolunas, Yu.V. (2002). Preliminary reports of geological studies within Schirmacher oasis during 47 RAE. In: Research and environment protection in Antarctica. Abstracts Volume. 2002. St.Petersburg. AARI. pp. 64-66 (in Russian).

Laiba, A.A., Andronikov, A.V., Egorov, L.S. \& Fedorov, L.V. (1987). Stock and dyke bodies of alkaline-ultrabasic composition at Jetty Peninsula (Prince Charles Mountains, East Antarctica). In: Geological-geophysical investigations in Antarctica. Ivanov, V.L. \& Grikurov, G.E. (eds). Sevmorgeologia. Leningrad. pp. 35-47 (in Russian).

Lawver, L.A., Sclater, J.G. \& Meinke, L. (1985). Mesozoic and Cenozoic reconstruction of the South Atlantic. Tectonophysics, Vol.114, pp. 233-254.

Leat, P.T., Curtis, M.L., Riley, T.R. \& Ferraccioli, F. (2007). Jurassic magmatism in Dronning Maud Land: synthesis of results of the MAMOG project. U.S. Geological Survey and the National Academies. USGS OF-2007- 1047. Short Research Paper 033; doi: 10.3133/of2007-1047 srp033.

Leitch, A.M., Davies, G.F. \& Wells, M. (1998). A plume head melting under a rifting margin. Earth and Planetary Science Letters, Vol.161, pp. 161-177.

Leitchenkov, G.L. \& Masolov, V.N. (1997). Tectonic and magmatic history of the Eastern Weddell Sea Region. In: The Antarctic Region: Geological Evolution and Processes. pp. 461-466.

Leitchenkov, G.L., O'Brien, P.E., Ishihara, T. \& Gandyukhin, V.V. (1999). The rift structure of Prydz Bay - Cooperation Sea and history of pre-breakup crustal extension between India and Antarctica. In: Abstracts of $8^{\text {th }}$ International Symp. on Antarctic Earth Sciences, New Zealand. pp. 188-190.

Leitchenkov, G.L., Sushchevskaya, N.M. \& Belyatsky, B.V. (2003). Geodynamics of the Atlantic and Indian Sectors of the South Ocean. Doklady Earth Sciences, Vol.391, pp. 675-678.

Leitchenkov, G.L. \& Guseva, Yu.B. (2006). Structure and Evolution of the Earth's Crust of the Sedimentary Basin of the Davis Sea, East Antarctica. In: Scientific Results of Geological and Geophysical Studies in Antarctica. Leitchenkov, G.L. \& Laiba, A.A. (eds). VNIIOkeanologiya, St. Petersburg, 2006. Vol.1, pp. 101-115 (in Russian).

Luttinen, A.V. \& Furnes, H. (2000). Flood basalts of Vestfjella: Jurassic magmatism across an Archaen-Proterozoic lithospheric boundary in Dronning Maud Land. Antarctica. Journal of Petrology, Vol.41, pp.1271-1305. 
Luttinen, A.V., Zhang, X. \& Foland, K.A. (2002). 159 Ma Kjakebeinet lamproites (Dronning Maud Land. Antarctica) and their implications for Gondwana breakup process. Geological Magazine, Vol.139, No.5, pp. 525-539.

Mahoney, J.J., Jones, W.B., Frey, F.A. \& et al. (1995). Geochemical characteristics of lavas from Broken Ridge. the Naturaliste Plateau and southernmost Kerguelen Plateau: Cretaceous plateau volcanism in the southeast Indian Ocean. Chemical Geology, Vol.120, pp. 315-345.

Martin, P.K. \& Hartnady, C. (1986). Plate tectonic development of the southwest Indian Ocean: a revised reconstruction of East Antarctica and Africa. Journal of Geophysical Research, Vol.91, pp. 4767-4785.

Migdisova, N.A., Sushchevskaya, N.M., Lattenen, A.V., \& Mikhalskii, E.M. (2004). Variations in the Composition of Clinopyroxene from the Basalts of Various Geodynamic Settings of the Antarctic Region. Petrology, Vol.12, pp. 176-194.

Mikhalsky, E.V., Andronikov, A.V. \& Beliatsky, B.V. (1992). Mafic igneous suites in the Lambert rift zone. In: Recent Progress in Antarctic Earth Science. Yoshida, Y., Kaminuma K. \& Shiraishi, K. (eds). Terrapub, Tokyo, pp. 173-178.

Mikhalsky, E.V., Laiba, A.A. \& Surina, N.P. (1998). The Lambert Province of alkaline-basic and alkaline-ultrabasic rocks in East Antarctica: geochemical and genetic characteristics of igneous complexes. Petrology, Vol.6, pp. 466-479.

Morgan, W.J. (1981). Hotspot tracks and opening of the Atlantic and Indian Oceans. In: The Sea. Emiliani, C. (ed.). 1981. Vol.7, New York. Wiley Interscience. pp. 443-487.

Nimis, P. \& Ulmer, P. (1998). Clinopyroxene geobarometry of magmatic rocks Part 1: An expanded structural geobarometer for anhydrous and hydrous. basic and ultrabasic systems. Contributions to Mineralogy and Petrology, Vol.133, pp. 122-135.

Ono, S., Ito, E. \& Katsura, T. (2001). Mineralogy of subducted basaltic crust (MORB) from 25 to $37 \mathrm{GPa}$, and chemical heterogeneity of the lower mantle. Earth and Planetary Science Letters, Vol.190, pp. 57-63.

O'Reilly, S.Y. \& Griffin, W.L. (2010). The continental lithosphere-asthenosphere boundary: Can we sample it? Lithos, Vol.120, pp. 1-13.

Pushcharovskii, Yu.M. \& Pushcharovskii, D.Yu. (1999). Geosphere of the Earth mantle. Geotectonica, No.1, pp. 3-14 (in Russian).

Renne, P.R., Glen, J.M., Milner, S.C. \& Duncan, R.A. (1996). Age of Etendeka-flood volcanism and associated intrusions in southwestern Africa. Geology, Vol.24, No.7, pp. 659-662.

Riley, T.R., Leat, P.T., Storey, B.C. \& et al. (2003). Ultramafic lamprophyres of the Ferrar large igneous province: evidence for a HIMU mantle component. Lithos, Vol.66, pp. 63-76.

Riley, T.R., Leat, P.T., Curtis, M.L. \& et al. (2005). Early-Middle Jurassic dolerite dykes from Western Dronning Maud Land (Antarctica): identifying mantle source in Karoo large igneous province. Journal of Petrology, Vol.46, No.7, pp. 1489-1524.

Ruzhentsev, S.V., Melankholina, E.N. \& Mossakovsky, A.A. (1999). Phanerozoic geodynamics of the Pacific Ocean and Indian-Atlantic segments of the Earth and mantle structure. in: Some problems of lithospheric geodynamics. 1999. N. 511. Lukianov, A.V. (ed.) Moscow. Nauka. pp. 27-43 (in Russian).

Sobolev, A.V., Hofmann, A.W., Sobolev, A.V. \& Nikogosian, I.K. (2005). An olivine-free mantle source of Hawaiian shield basalts. Nature, Vol.434, N7033, pp. 590-597.

Sobolev, A.V., Hofmann, A.W., Kuzmin, D.V. \& et al. (2007). The amount of recycled crust in sources of mantle-derived melts. Science, Vol.316, pp. 412-417. 
Stewart, K., Turner, S., Kelly, S. \& et al. (1996). ${ }^{40} \mathrm{Ar} /{ }^{39} \mathrm{Ar}$ geochronology in the Parana continental flood basalt province. Earth and Planetary Science Letters, Vol.143, No.1-2, pp. 95-109.

Storey, B.C. (1995). The role of mantle plumes in continental breakup: case histories from Gondwanaland. Nature, Vol.377, pp. 301-308.

Storey, B.C. \& Kyle, P.R. (1997). An active mantle mechanism for Gondwana break-up. South African Journal of Geology, Vol.100, pp. 283-290.

Storey, M., Saunders, A.D., Tarney, J., et al. (1989). Contamination of Indian Ocean asthenosphere by the Kerguelen-Heard mantle plume. Nature, Vol.338, pp. 574-576.

Storey, M., Kent, R.W., Saunders, A.D. \& et al. (1992). Lower Cretaceous volcanic rocks on continental margins and their relationships to the Kerguelen Plateau. In: Proceedings of ODP Scientific Results. Wise, S.W.J. \& Schlich, R. (eds). 1992. Vol.120. pp. 33-53.

Sun, S.-S. \& McDonough, W.F. (1989). Chemical and isotopic systematics of oceanic basalts: implications for mantle composition and processes. In: Magmatism in the ocean basins. Saunders, A.D. \& Norry, M.J. (eds). 1989. Geol. Soc. Spec. Publ. Vol.42, pp.313-345.

Sushchevskaya, N.M., Ovchinnikova, G.V., Borisova, A.Yu. \& et al. (1996). Geochemical Heterogeneity of the Magmatism of Afanasij Nikitin Rise, Northeastern Indian Ocean. Petrology, Vol.4, pp.119-136.

Sushchevskaya, N.M., Belyatskii, B.V., Tsekhonya, T.I. \& et al. (1998). Petrology and Geochemistry of Basalts from the Eastern Indian Ocean: Implications for Its Early Evolution. Petrology, Vol.6, pp. 528-555.

Sushchevskaya, N.M., Belyatskii, B.V, Dubinin, E.P. \& et al. (2003). Geochemical Heterogeneity of Tholeiitic Magmatism in Circum-Antarctic Rift Zones. Geochemistry International, Vol.41, pp. 727-740.

Sushchevskaya, N.M., Mikhalskii, E.M. \& Belyatskii, B.V. (2004). Magmatic evolution of the South sector of the Earth. In: Petrology of magmatic and metamorphic complexes, No.4, 2004. Tomsk. pp. 219-223.

Sushchevskaya, N.M., Cherkashov, G.A., Baranov, B.V. et al. (2005). Tholeiitic Magmatism of an Ultraslow Spreading Environment: An Example from the Knipovich Ridge, North Atlantic. Geochemistry International, Vol.43, pp. 222-241.

Sushchevskaya, N.M., Korago, E.A., Belyatsky, B.V. \& Sirotkin, A.N. (2009). Geochemistry of Neogene Magmatism at Spitsbergen Island. Geochemistry International, Vol.47, pp. 966-978.

Vuori, S.K. \& Luttinen, A.V. (2003). The Jurassic gabbroic intrusions of Utpostane and Muren: insights into Karoo-related plutonism in Dronning Maud Land. Antarctica. Antarctic Science, Vol.15, pp. 283-301.

Weis, D., Frey, F.A., Saunders, A. \& Leg 121 team. (1991). Ninetyeast Ridge (Indian Ocean): a $500 \mathrm{~km}$ record of a Dupal mantle plume. Geology, Vol.19, pp. 99-102.

Weis, D. \& Frey, F.A. (1996). Role of the Kerguelen Plume in generating the eastern Indian Ocean seafloor. Journal of Geophysical Research, Vol.101, No.B6, pp. 13831-13849.

White, R. \& McKenzie, D. (1989). Magmatism at rift zones: the generating of volcanic continental margins and flood basalts. Journal of Geophysical Research, Vol.94, pp. 7685-7729.

Zhang, X., Luttinen, A.V., Elliot, D.H. \& et al. (2003). Early stages of Gondwana breakup: the ${ }^{40} \mathrm{Ar} /{ }^{39} \mathrm{Ar}$ geochronology of Jurassic basaltic rocks from western Dronning Maud Land, Antarctica, and implications for the timing of magmatic and hydrothermal events. Journal of Geophysical Research, Vol.108, No.B9, pp. 2449-2466. doi: 10.1029/2001JB001070. 


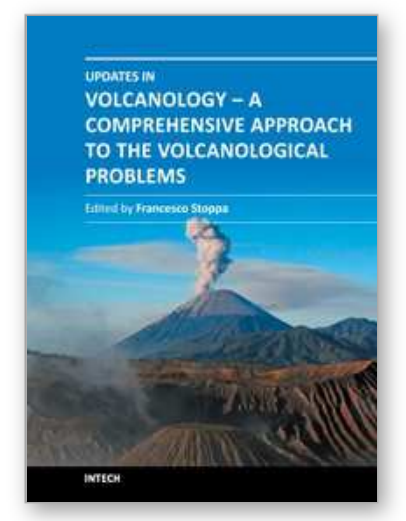

\section{Updates in Volcanology - A Comprehensive Approach to Volcanological Problems}

Edited by Prof. Francesco Stoppa

ISBN 978-953-307-434-4

Hard cover, 242 pages

Publisher InTech

Published online 13, January, 2012

Published in print edition January, 2012

This book ranges from the geologic-petrologic description of world-wide major volcanic fields unfamiliar to international literature, to the discussion and interpretation of the results in light of geophysical techniques. It focuses on several situations that represent large-scale volcanism on Earth, related both with intra-plate or active margins. Many large volcanic complexes of Easter countries are presented, including Japan, Siberian Russia, and Mongolia. A detailed account of the European volcanic province of the Pannonia basin and Central-Southern Spain is given. Southern hemisphere areas of Antarctica and Polynesia are considered as well. The chapters are very informative for those who wish for a guide to visiting, or are curious about main characteristics of the above volcanic areas, some of which are remote and not easily accessible.

\section{How to reference}

In order to correctly reference this scholarly work, feel free to copy and paste the following:

Nadezhda M. Sushchevskaya, Boris V. Belyatsky and Anatoly A. Laiba (2012). Origin, Distribution and Evolution of Plume Magmatism in East Antarctica, Updates in Volcanology - A Comprehensive Approach to Volcanological Problems, Prof. Francesco Stoppa (Ed.), ISBN: 978-953-307-434-4, InTech, Available from: http://www.intechopen.com/books/updates-in-volcanology-a-comprehensive-approach-to-volcanologicalproblems/origin-distribution-and-evolution-of-plume-magmatism-in-east-antarctica

\section{INTECH}

open science | open minds

\author{
InTech Europe \\ University Campus STeP Ri \\ Slavka Krautzeka 83/A \\ 51000 Rijeka, Croatia \\ Phone: +385 (51) 770447 \\ Fax: +385 (51) 686166 \\ www.intechopen.com
}

\author{
InTech China \\ Unit 405, Office Block, Hotel Equatorial Shanghai \\ No.65, Yan An Road (West), Shanghai, 200040, China \\ 中国上海市延安西路65号上海国际贵都大饭店办公楼 405 单元 \\ Phone: +86-21-62489820 \\ Fax: +86-21-62489821
}


(C) 2012 The Author(s). Licensee IntechOpen. This is an open access article distributed under the terms of the Creative Commons Attribution 3.0 License, which permits unrestricted use, distribution, and reproduction in any medium, provided the original work is properly cited. 